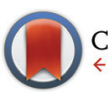

CrossMark \&lick for updates

Cite this: Polym. Chem., 2017, 8 , 1163

Received 16th November 2016, Accepted 25th December 2016 DOI: $10.1039 / c 6 p y 02004 f$ rsc.li/polymers

\section{Oxygen and carbon dioxide dual gas-responsive homopolymers and diblock copolymers synthesized via RAFT polymerization $\uparrow$}

\begin{abstract}
Xue Jiang, ${ }^{a}$ Feng Chun, ${ }^{a, b}$ Guolin $\mathrm{Lu}^{\mathrm{a}}$ and Huang Xiaoyu*a
The monomer, 2,2,2-trifluoroethyl 3-( $\mathrm{N}$-(2-(diethylamino)ethyl)acrylamido)propanoate (TF-DEAE-AM), which contains both $\mathrm{O}_{2}$ and $\mathrm{CO}_{2}$-responsive functionalities, was first synthesized from commercially available $N, N$-diethylethylenediamine, 2,2,2-trifluoroethyl acrylate, and acryloyl chloride. Subsequently, a series of dual-gas responsive polymers, poly(2,2,2-trifluoroethyl 3-( $N$-(2-(diethylamino)ethyl)acrylamido) propanoate) (poly(TF-DEAE-AM)) and poly(ethylene glycol)-b-poly(2,2,2-trifluoroethyl 3-( $\mathrm{N}$-(2-(diethylamino)ethyl)acrylamido)propanoate) (PEG-b-poly(TF-DEAE-AM)), were synthesized by employing reversible addition-fragmentation chain transfer (RAFT) polymerization. Due to the protonation between $\mathrm{CO}_{2}$ and DEAE groups, and the specific van der Waals interactions between $\mathrm{O}_{2}$ and $\mathrm{C}-\mathrm{F}$ bonds, micelles consisting of poly(TF-DEAE-AM) or PEG-b-poly(TF-DEAE-AM) display distinct $\mathrm{CO}_{2}$ and $\mathrm{O}_{2}$ responsiveness in aqueous media. Pyrene, which is a model hydrophobic drug, is able to be effectively encapsulated in the micelles based on PEG- $b$-poly(TF-DEAE-AM). It is found that the release of pyrene sharply increases after bubbling $\mathrm{CO}_{2}$ or $\mathrm{O}_{2}$ compared to $\mathrm{N}_{2}$, and the release rate of the solution bubbling with $\mathrm{CO}_{2}$ is the fastest. Since both $\mathrm{CO}_{2}$ and $\mathrm{O}_{2}$ are key gases for the human body, the $\mathrm{CO}_{2}-$ and $\mathrm{O}_{2}$-induced release property of poly(TF-DEAE-AM) may open opportunities for the preparation of functional materials with special $\mathrm{CO}_{2}$ and $\mathrm{O}_{2}$ responsiveness for potential applications in biomedicine.
\end{abstract}

\section{Introduction}

Environmentally responsive polymers have attracted significant attention in the last decade due to their prospective applications in biomedicine, nano-therapeutics, and gene transportation. ${ }^{1-6}$ As a type of "smart" polymer, their solubility, conformation, or chemical structure, e.g. breakage or formation of covalent and non-covalent bonds, can be tuned in response to an external trigger, such as temperature, ${ }^{7,8} \mathrm{pH},{ }^{9,10}$ light, ${ }^{11,12}$ ionic strength, ${ }^{13}$ and redox. ${ }^{14}$

Recently, intensive attention has been paid to abundant and environmentally benign gas stimulation modes, including $\mathrm{CO}_{2}, \mathrm{O}_{2}$, and NO. The reversible and dynamic features of gas-responsive polymers make them suitable and desirable for

\footnotetext{
${ }^{a}$ Key Laboratory of Synthetic and Self-Assembly Chemistry for Organic Functional Molecules, Shanghai Institute of Organic Chemistry, Chinese Academy of Sciences, 345 Lingling Road, Shanghai 200032, People's Republic of China.

E-mail: cfeng@mail.sioc.ac.cn, xyhuang@mail.sioc.ac.cn; Fax: +86-21-64166128; Tel: +86-21-54925606, +86-21-54925310

${ }^{b}$ State Key Laboratory of Molecular Engineering of Polymers, Department of Macromolecular Science, Fudan University, 220 Handan Road, Shanghai 200433, People's Republic of China

$\dagger$ Electronic supplementary information (ESI) available. See DOI: 10.1039/ c6py02004f
}

biomedical applications, including controlled drug release, tissue culture, and peripheral vascular embolization materials. ${ }^{15-28}$ Among them, $\mathrm{CO}_{2}$-responsive polymers have gained growing interest. On one hand, they can be reversibly protonated by introducing $\mathrm{CO}_{2}$ with an increase in their solubility or deprotonated by bubbling an inert gas, such as $\mathrm{N}_{2}$ or Ar, with a decrease in their solubility in an aqueous solution. On the other hand, since $\mathrm{CO}_{2}$ is a key metabolite for life and has good biocompatibility and membrane permeability, $\mathrm{CO}_{2}$ responsive polymers have potential applications in sensors, surface adhesives, and drug delivery. ${ }^{15-24}$ For example, Yuan et al. developed the new idea of utilizing a specific amidinecontaining block copolymer to fabricate $\mathrm{CO}_{2}$-responsive vesicles with a biomimetic "breathing" feature, and the membrane permeability of the vesicles can be simply tuned by regulating the $\mathrm{CO}_{2}$ stimulation time. ${ }^{17}$ By utilization of the controlled semi-permeability of $\mathrm{CO}_{2}$-responsive polymers, hierarchical cargo release and selective separation of guest molecules could be easily realized. ${ }^{18}$ In addition to the amidine group, some polymers containing tertiary amine groups, such as poly $((N, N$ dimethylamino)ethyl methacrylate) (PDMAEMA) and poly $((N, N$ diethylamino)ethyl methacrylate) (PDEAEMA), were proven to possess $\mathrm{CO}_{2}$ responsiveness. ${ }^{20-24}$ For instance, Zhao et al. designed a series of triblock copolymers composed of an outer 
hydrophilic poly(ethylene oxide) segment, middle hydrophobic polystyrene bridging block, and $\mathrm{CO}_{2}$-responsive interior PDEAEMA flank, which could mimic gas-controllable diversiform deformations of organelles. ${ }^{24}$ Similar to $\mathrm{CO}_{2}, \mathrm{O}_{2}$ is another important gas trigger. Both aromatic and aliphatic fluoro-substituted polymers have unique $\mathrm{O}_{2}$ responsiveness because of the special van der Waals interactions between $\mathrm{O}_{2}$ molecules and $\mathrm{C}-\mathrm{F}$ bonds. ${ }^{25-29}$ Zhu et al. reported the synthesis of a new type of fluorinated copolymer via the atom transfer radical polymerization (ATRP) of commercially available 2,2,2-trifluoroethyl methacrylate (TFMA) and $N, N$-dimethylaminoethyl methacrylate (DMAEMA). ${ }^{26}$ The obtained copolymer showed a prominent increase in lower critical solution temperature (LCST) from $24.5^{\circ} \mathrm{C}$ to $50{ }^{\circ} \mathrm{C}$ by the bubbling of $\mathrm{O}_{2}$, which probably results from its improved solubility due to the interactions between $\mathrm{O}_{2}$ molecules and 2,2,2trifluoroethyls.

In contrast to a single-stimulus system, a multi-stimuli system may show a synergistic effect, thereby enhancing the recognition efficiency for distinct drug delivery and release behaviors. ${ }^{30-34}$ Since both $\mathrm{CO}_{2}$ and $\mathrm{O}_{2}$ are important to life, the design of dual gas-responsive polymers will significantly expand the scope of stimuli-responsive materials. Although dual $\mathrm{CO}_{2}$ - and $\mathrm{O}_{2}$-responsive polymers can be prepared by block or random copolymerization of $\mathrm{CO}_{2}$ - and $\mathrm{O}_{2}$-responsive monomers, the time-consuming steps in the preparation and purification of block copolymers and ill-defined monomer distribution of random copolymer are inherent drawbacks of the block and random copolymer systems, respectively. ${ }^{27,28}$ In order to avoid these drawbacks, installation of $\mathrm{CO}_{2}^{-}$and $\mathrm{O}_{2}$-responsive functionalities into the same repeated unit on the basis of the maturity of organic synthesis, that is, the preparation of $\mathrm{CO}_{2}$ - and $\mathrm{O}_{2}$-responsive homopolymers, has been considered as an effective and promising alternative. Therefore, it is not surprising that homopolymers with multistimuli responsiveness have drawn growing interest in polymer science. ${ }^{35-39}$ However, to the best of our knowledge, the currently available multi-stimuli responsive homopolymers are mainly based on temperature and $\mathrm{pH}$ stimuli, and reports on the synthesis of homopolymers with $\mathrm{CO}_{2}$ and $\mathrm{O}_{2}$ responsiveness are rare. ${ }^{29}$

In this study, we develop a new strategy to prepare homopolymers with $\mathrm{CO}_{2}$ and $\mathrm{O}_{2}$ responsiveness by the installation of $\mathrm{CO}_{2}$ - and $\mathrm{O}_{2}$-responsive functional groups in the same repeated unit. Commercially available $\mathrm{N}, \mathrm{N}$-diethylethylenediamine (DEAE) and 2,2,2-trifluoroethyl acrylate are first connected by the aza-Michael addition reaction (Scheme 1) to give 2,2,2-trifluoroethyl 3-(2-(diethylamino)ethylamino)-propanoate (TF-DEAE). Next, the new monomer, 2,2,2trifluoroethyl 3-( $N$-(2-(diethylamino)ethyl)acrylamido)propanoate (TF-DEAE-AM), was obtained by the reaction between TF-DEAE and acryloyl chloride. Subsequently, the target poly (TF-DEAE-AM) homopolymers are prepared by reversible addition-fragmentation chain transfer (RAFT) polymerization using 4-cyano-4-(dodecylsulfanylthiocarbonylsulfanyl)pentanoic acid (CDSTSP) as the chain transfer agent with controlled molecular weights and relatively narrow molecular weight distributions. The $\mathrm{CO}_{2}$ and $\mathrm{O}_{2}$ responsiveness of the obtained homopolymers are examined via TEM, ${ }^{1} \mathrm{H}$ NMR, ${ }^{19} \mathrm{~F}$ NMR, DLS, and UV-vis spectroscopy. In addition, PEG- $b$-poly (TF-DEAE-AM) diblock polymers are prepared by the RAFT polymerization of TF-DEAE-AM using a PEG-based macromolecular chain transfer agent instead of CDSTSP. It is observed that a variation in both $\mathrm{CO}_{2}$ and $\mathrm{O}_{2}$ not only induces a change in the morphology of the aggregates in the aqueous media, but also results in difference in release profiles for hydro-
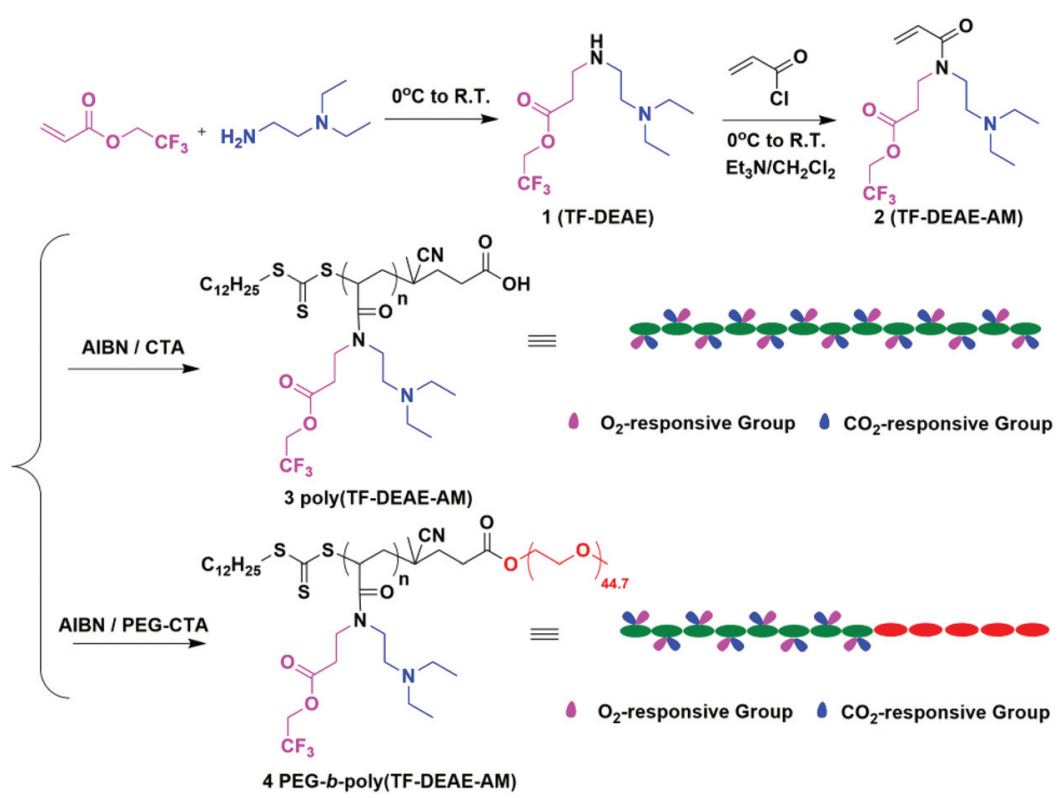

Scheme 1 Synthetic route for poly(TF-DEAE-AM) and PEG-b-poly(TF-DEAE-AM). 
phobic dye (pyrene) loading in micelles based on PEG-b-poly (TF-DEAE-AM). The $\mathrm{CO}_{2^{-}}$and $\mathrm{O}_{2}$-induced release property of poly(TF-DEAE-AM) may open opportunities for the preparation of functional materials with special $\mathrm{CO}_{2}$ and $\mathrm{O}_{2}$ responsiveness for potential applications in biomedicine.

\section{Experimental}

\section{Materials}

2,2'-Azobis(isobutyronitrile) (AIBN, Aldrich, 98\%) was recrystallized from anhydrous ethanol. Tetrahydrofuran (THF, Aldrich, 99\%) and dichloromethane $\left(\mathrm{CH}_{2} \mathrm{Cl}_{2}\right.$, Aldrich, 99\%) were dried over $\mathrm{CaH}_{2}$ and distilled from sodium and benzophenone under $\mathrm{N}_{2}$, prior to use. Triethylamine $\left(\mathrm{Et}_{3} \mathrm{~N}\right.$, Aldrich, 99.5\%) was dried over $\mathrm{KOH}$ and distilled over $\mathrm{CaH}_{2}$ under $\mathrm{N}_{2}$, prior to use. N-Phenyl-1-naphthylamine (PNA, Alfa Aesar, 97\%) was purified by recrystallization in ethanol three times. 4-Dimethylaminopyridine (DMAP, Aldrich, 98\%) was recrystallized three times from toluene. 2,2,2-Trifluoroethyl acrylate (TCI, 98\%), N,N-diethylethylenediamine (DEAE, J\&K, 99\%), $N, N^{\prime}$-dicyclohexylcarbodiimide (DCC, Aldrich, 99\%), acryloyl chloride (Aladdin, 96\%), and poly(ethylene glycol) monomethyl ether (PEG-OH, $M_{\mathrm{n}}=2000 \mathrm{~g} \mathrm{~mol}^{-1}$, Aldrich, 99\%) were used as received. 4-Cyano-4-(dodecylsulfanyl-thiocarbonylsulfanyl)pentanoic acid (CDSTSP) was synthesized according to previous literature. ${ }^{42}$

\section{Measurements}

All ${ }^{1} \mathrm{H},{ }^{13} \mathrm{C}$, and ${ }^{19} \mathrm{~F}$ NMR analyses were performed on a JEOL ECZ 400S spectrometer (400 $\mathrm{MHz}$ ) in $\mathrm{CDCl}_{3}$ and $\mathrm{D}_{2} \mathrm{O}$; tetramethylsilicone $\left({ }^{1} \mathrm{H}\right)$ and $\mathrm{CDCl}_{3}\left({ }^{13} \mathrm{C}\right)$ were used as internal standards, and $\mathrm{CF}_{3} \mathrm{CO}_{2} \mathrm{H}$ was used as the external standard for ${ }^{19} \mathrm{~F}$ NMR. FT-IR spectra were recorded on a Nicolet AVATAR-360 spectrophotometer with a $4 \mathrm{~cm}^{-1}$ resolution. Elemental analysis was carried out on a Carlo-Erba 1106 system. Relative molecular weights and molecular weight distributions were measured using a conventional gel permeation chromatography (GPC) system equipped with a Waters 515 Isocratic HPLC pump, Waters 2414 refractive index detector, and a set of Waters Styragel columns (HR3 (500-30000), HR4 (5000-600 000), and HR5 (50 000-4 000000$), 7.8 \times 300 \mathrm{~mm}$, particle size: $5 \mu \mathrm{m}$ ). GPC measurements were carried out at $35{ }^{\circ} \mathrm{C}$ using $\mathrm{THF}$ as the eluent with a flow rate of 1.0 $\mathrm{mL} \mathrm{min}^{-1}$. The system was calibrated with linear poly(methyl methacrylate) (PMMA) standards. The transmittance of polymer solutions and UV-vis spectra were measured using a Hitachi U-2910 spectrophotometer. Steady-state fluorescence spectra were measured at $20{ }^{\circ} \mathrm{C}$ on a Hitachi F-2700 fluorescence spectrophotometer with the band width of $5 \mathrm{~nm}$ for excitation and emission, and the emission intensity at $418 \mathrm{~nm}$ was recorded to determine the critical micelle concentration (cmc), where the excitation wavelength $\left(\lambda_{\mathrm{ex}}\right)$ was $340 \mathrm{~nm}$. Hydrodynamic diameter $\left(D_{\mathrm{h}}\right)$ was measured by dynamic light scattering (DLS) with a Malvern Nano ZS90 Zetasizer after equilibrating for $2 \mathrm{~min}$ at $20^{\circ} \mathrm{C}$. The zeta-potential of the solutions containing polymer aggregates was determined in $\mathrm{KCl}$ aqueous media $(5.0 \mathrm{mM})$ at $25{ }^{\circ} \mathrm{C}$ on a Malvern Nano ZS90 Zetasizer. Transmission electron spectroscopy (TEM) images were obtained on a JEOL JEM-1230 instrument operated at $80 \mathrm{kV}$.

\section{Synthesis of 2,2,2-trifluoroethyl 3-(2-(diethylamino) ethylamino)propanoate}

$N, N$-Diethylethylenediamine $(8.4 \mathrm{~g}, 72.0 \mathrm{mmol})$ was added dropwise to 2,2,2-trifluoroethyl acrylate $(9.3 \mathrm{~mL}, 60.0 \mathrm{mmol})$ at $0{ }^{\circ} \mathrm{C}$. The reaction mixture was stirred at $0{ }^{\circ} \mathrm{C}$ for $30 \mathrm{~min}$ and then at room temperature for additional $12 \mathrm{~h}$. The mixture was purified via flash chromatography (silica gel column, eluent: ethyl acetate/hexane $\left(\mathrm{v}: \mathrm{v}=1: 4\right.$ with $\left.\left.\mathrm{Et}_{3} \mathrm{~N}\right)\right)$ to give $8.5 \mathrm{~g}(52.4 \%$ yield) of amine 1, 2,2,2-trifluoroethyl 3-(2-(diethylamino)ethylamino)propanoate (TF-DEAE). FT-IR: $\nu\left(\mathrm{cm}^{-1}\right): 3313,2971,2935$, 2816, 1760, 1453, 1412, 1384, 1283, 1168, 1068, 976. ${ }^{1} \mathrm{H}$ NMR $\left(400 \mathrm{MHz}, \mathrm{CDCl}_{3}\right): \delta$ (ppm): $0.97\left(6 \mathrm{H}, \mathrm{CH}_{2} \mathrm{~N}\left(\mathrm{CH}_{2} \mathrm{CH}_{3}\right)_{2}\right)$, $1.78\left(1 \mathrm{H}, \mathrm{O}_{2} \mathrm{CCH}_{2} \mathrm{CH}_{2} \mathrm{NHCH}_{2}\right), 2.49\left(6 \mathrm{H}, \mathrm{CH}_{2} \mathrm{~N}\left(\mathrm{CH}_{2} \mathrm{CH}_{3}\right)_{2}\right)$, $2.62\left(4 \mathrm{H}, \mathrm{O}_{2} \mathrm{CCH}_{2} \mathrm{CH}_{2} \mathrm{NHCH}_{2}\right), 2.91\left(2 \mathrm{H}, \mathrm{O}_{2} \mathrm{CCH}_{2} \mathrm{CH}_{2} \mathrm{NHCH}_{2}\right)$, $4.45\left(2 \mathrm{H}, \mathrm{CO}_{2} \mathrm{CH}_{2} \mathrm{CF}_{3}\right) .{ }^{13} \mathrm{C} \mathrm{NMR}\left(101 \mathrm{MHz}, \mathrm{CDCl}_{3}\right): \delta$ (ppm): $11.9 \quad\left(\mathrm{CH}_{2} \mathrm{~N}\left(\mathrm{CH}_{2} \mathrm{CH}_{3}\right)_{2}\right), \quad 34.5 \quad\left(\mathrm{O}_{2} \mathrm{CCH}_{2} \mathrm{CH}_{2} \mathrm{NHCH}_{2}\right), \quad 45.0$ $\left(\mathrm{O}_{2} \mathrm{CCH}_{2} \mathrm{CH}_{2} \mathrm{NHCH}_{2}\right), \quad 47.2 \quad\left(\mathrm{CH}_{2} \mathrm{~N}\left(\mathrm{CH}_{2} \mathrm{CH}_{3}\right)_{2}\right), \quad 47.5$ $\left(\mathrm{O}_{2} \mathrm{CCH}_{2} \mathrm{CH}_{2} \mathrm{NHCH}_{2}\right), 52.7\left(\mathrm{CH}_{2} \mathrm{~N}\left(\mathrm{CH}_{2} \mathrm{CH}_{3}\right)_{2}\right), 60.3\left(\mathrm{CO}_{2} \mathrm{CH}_{2} \mathrm{CF}_{3}\right)$, $123.1\left(\mathrm{CO}_{2} \mathrm{CH}_{2} \mathrm{CF}_{3}\right), 171.2\left(\mathrm{CO}_{2} \mathrm{CH}_{2} \mathrm{CF}_{3}\right) .{ }^{19} \mathrm{~F}$ NMR $(376 \mathrm{MHz}$, $\left.\mathrm{CDCl}_{3}\right): \quad \delta$ (ppm): $-73.9 \quad\left(\mathrm{CO}_{2} \mathrm{CH}_{2} \mathrm{CF}_{3}\right)$. Anal. Calcd for $\mathrm{C}_{11} \mathrm{H}_{21} \mathrm{~N}_{2} \mathrm{O}_{2} \mathrm{~F}_{3}$ : C, 48.88\%; H, 7.83\%; N, 10.36\%. Found: C, $48.46 \%$; H, $7.83 \%$; N, 10.16\%.

\section{Synthesis of 2,2,2-trifluoroethyl 3-(N-(2-(diethylamino)ethyl) acrylamido)-propanoate}

2,2,2-Trifluoroethyl 3-(2-(diethylamino)ethylamino)propanoate $(8.1 \mathrm{~g}, 30.0 \mathrm{mmol})$ and $\mathrm{Et}_{3} \mathrm{~N}(10.0 \mathrm{~mL}, 72.0 \mathrm{mmol})$ were dissolved in $100 \mathrm{~mL}$ of anhydrous $\mathrm{CH}_{2} \mathrm{Cl}_{2}$. The solution was cooled to $0{ }^{\circ} \mathrm{C}$, followed by the addition of acryloyl chloride (3.3 g, $36.0 \mathrm{mmol}$ ) dropwise within $15 \mathrm{~min}$. The mixture was slowly warmed to room temperature and stirred for $12 \mathrm{~h}$. The volatiles were evaporated under reduced pressure and the residue was purified using flash chromatography (silica gel column, eluent: ethyl acetate/hexane $\left(\mathrm{v}: \mathrm{v}=1: 4\right.$ with $\left.\left.^{\mathrm{Et}} \mathrm{t}_{3} \mathrm{~N}\right)\right)$ to give $3.0 \mathrm{~g}$ (30.9\% yield) of the corresponding acrylamide monomer 2, 2,2,2-trifluoroethyl 3-( $\mathrm{N}$-(2-(diethylamino)-ethyl) acrylamido)propanoate (TF-DEAE-AM). FT-IR: $\nu\left(\mathrm{cm}^{-1}\right): 2970$, 2937, 2810, 1758, 1652, 1615, 1448, 1425, 1374, 1281, 1169, 1071, 977, 785. ${ }^{1} \mathrm{H}$ NMR (400 $\left.\mathrm{MHz}, \mathrm{CDCl}_{3}\right): \delta(\mathrm{ppm}): 0.99(6 \mathrm{H}$, $\left.\mathrm{CH}_{2} \mathrm{~N}\left(\mathrm{CH}_{2} \mathrm{CH}_{3}\right)_{2}\right), 2.51\left(6 \mathrm{H}, \mathrm{CH}_{2} \mathrm{~N}\left(\mathrm{CH}_{2} \mathrm{CH}_{3}\right)_{2}\right), 2.77 \quad(2 \mathrm{H}$, $\left.\mathrm{O}_{2} \mathrm{CCH}_{2} \mathrm{CH}_{2} \mathrm{NCH}_{2}\right), \quad 3.43 \quad\left(2 \mathrm{H}, \quad \mathrm{O}_{2} \mathrm{CCH}_{2} \mathrm{CH}_{2} \mathrm{NCH}_{2}\right), \quad 3.67$ $\left(2 \mathrm{H}, \mathrm{O}_{2} \mathrm{CCH}_{2} \mathrm{CH}_{2} \mathrm{NCH}_{2}\right), 4.44\left(2 \mathrm{H}, \mathrm{CO}_{2} \mathrm{CH}_{2} \mathrm{CF}_{3}\right), 5.68,6.32$ $\left(2 \mathrm{H}, \quad \mathrm{CH}_{2}=\mathrm{CHCO}\right), \quad 6.54 \quad\left(1 \mathrm{H}, \quad \mathrm{CH}_{2}=\mathrm{CHCO}\right) . \quad{ }^{13} \mathrm{C} \quad \mathrm{NMR}$ $\left(101 \mathrm{MHz}, \mathrm{CDCl}_{3}\right): \delta$ (ppm): $12.0\left(\mathrm{CH}_{2} \mathrm{~N}\left(\mathrm{CH}_{2} \mathrm{CH}_{3}\right)_{2}\right), 32.4$ $\left(\mathrm{O}_{2} \mathrm{CCH}_{2} \mathrm{CH}_{2} \mathrm{NCH}_{2}\right), 43.8 \quad\left(\mathrm{CH}_{2} \mathrm{~N}\left(\mathrm{CH}_{2} \mathrm{CH}_{3}\right)_{2}\right), 47.6 \quad\left(\mathrm{CH}_{2} \mathrm{~N}\right.$ $\left.\left(\mathrm{CH}_{2} \mathrm{CH}_{3}\right)_{2}\right), 48.1\left(\mathrm{O}_{2} \mathrm{CCH}_{2} \mathrm{CH}_{2} \mathrm{NCH}_{2}\right), 52.7\left(\mathrm{O}_{2} \mathrm{CCH}_{2} \mathrm{CH}_{2} \mathrm{NCH}_{2}\right)$, $60.5\left(\mathrm{CO}_{2} \mathrm{CH}_{2} \mathrm{CF}_{3}\right), 121.6\left(\mathrm{CH}_{2}=\mathrm{CHCO}\right), 124.4\left(\mathrm{CH}_{2}=\mathrm{CHCO}\right)$, 128.0 $\left(\mathrm{CO}_{2} \mathrm{CH}_{2} \mathrm{CF}_{3}\right), 166.6\left(\mathrm{CH}_{2}=\mathrm{CHCO}\right), 170.7\left(\mathrm{CO}_{2} \mathrm{CH}_{2} \mathrm{CF}_{3}\right)$. ${ }^{19} \mathrm{~F}$ NMR $\left(376 \mathrm{MHz}, \mathrm{CDCl}_{3}\right): \delta(\mathrm{ppm}):-73.8\left(\mathrm{CO}_{2} \mathrm{CH}_{2} \mathrm{CF}_{3}\right)$. MS-DART: calculated $\mathrm{C}_{14} \mathrm{H}_{24} \mathrm{~N}_{2} \mathrm{O}_{3} \mathrm{~F}_{3}$ for 325.1734 ; found 
325.1732 $[\mathrm{M}+\mathrm{H}]^{+}$. Anal. Calcd for $\mathrm{C}_{14} \mathrm{H}_{23} \mathrm{~N}_{2} \mathrm{O}_{3} \mathrm{~F}_{3}$ : C, 51.84\%; H, 7.15\%; N, 8.64\%. Found: C, 51.86\%; H, 7.15\%; N, 8.67\%.

\section{RAFT homopolymerization of TF-DEAE-AM}

In a typical procedure, AIBN (1.6 mg, $0.01 \mathrm{mmol})$, CDSTSP (12.4 mg, $0.031 \mathrm{mmol}$ ), and TF-DEAE-AM (0.50 g, $1.54 \mathrm{mmol}$ ) were first added to a $25 \mathrm{~mL}$ Schlenk flask (flame-dried under vacuum prior to use) sealed with a rubber septum for degassing and kept under $\mathrm{N}_{2}$. Next, dry THF $(0.5 \mathrm{~mL})$ was charged via a gastight syringe. The flask was degassed by three cycles of freezing-pumping-thawing, followed by immersing the flask into an oil bath set at $65{ }^{\circ} \mathrm{C}$. The polymerization lasted for $15 \mathrm{~h}$ and it was terminated by placing the flask into liquid $\mathrm{N}_{2}$. The reaction mixture was precipitated in cold $n$-hexane. The crude product was purified by repeated dissolution in THF and precipitation in $n$-hexane, followed by drying in vacuo overnight to give $0.18 \mathrm{~g}$ of light yellow solid, poly (TF-DEAE-AM) 3b. GPC: $M_{\mathrm{n}}=10500 \mathrm{~g} \mathrm{~mol}^{-1}, M_{\mathrm{w}} / M_{\mathrm{n}}=1.36$. FT-IR: $\quad \nu \quad\left(\mathrm{cm}^{-1}\right):$ 2969, 2928, 2812, 1758, 1642, 1452, 1422, 1379, 1280, 1169, 1070, 976, 842. ${ }^{1} \mathrm{H}$ NMR $(400 \mathrm{MHz}$, $\left.\mathrm{CDCl}_{3}\right): \delta$ (ppm): $1.02\left(6 \mathrm{H}, \mathrm{CH}_{2} \mathrm{~N}\left(\mathrm{CH}_{2} \mathrm{CH}_{3}\right)_{2}\right), 1.25(18 \mathrm{H}$, $\left.\mathrm{SCH}_{2} \mathrm{CH}_{2}\left(\mathrm{CH}_{2}\right)_{9} \mathrm{CH}_{3}\right), \quad 1.79\left(2 \mathrm{H}, \mathrm{CH}_{2} \mathrm{CHCON}\right), \quad 2.58 \quad(1 \mathrm{H}$, $\left.\mathrm{CH}_{2} \mathrm{CHCON} ; 6 \mathrm{H}, \quad \mathrm{CH}_{2} \mathrm{~N}\left(\mathrm{CH}_{2} \mathrm{CH}_{3}\right)_{2} ; 2 \mathrm{H}, \mathrm{O}_{2} \mathrm{CCH}_{2} \mathrm{CH}_{2} \mathrm{NCH}_{2}\right)$, $3.58\left(4 \mathrm{H}, \mathrm{O}_{2} \mathrm{CCH}_{2} \mathrm{CH}_{2} \mathrm{NCH}_{2}\right), 4.46\left(2 \mathrm{H}, \mathrm{CO}_{2} \mathrm{CH}_{2} \mathrm{CF}_{3}\right)$.

\section{Preparation of PEG-CTA}

PEG-OH $\left(M_{\mathrm{n}}=2000 \mathrm{~g} \mathrm{~mol}{ }^{-1}, 25.0 \mathrm{~g}, 12.5 \mathrm{mmol}-\mathrm{OH}\right)$, DMAP (0.3 g, $2.5 \mathrm{mmol}$ ), CDSTSP (10.1 g, $25.0 \mathrm{mmol}$ ), and dry $\mathrm{CH}_{2} \mathrm{Cl}_{2}(300.0 \mathrm{~mL})$ were first added to a $500 \mathrm{~mL}$ flask (flamedried under vacuum prior to use) sealed with a rubber septum under $\mathrm{N}_{2}$. The solution was cooled to $0{ }^{\circ} \mathrm{C}$, followed by the addition of $25 \mathrm{~mL}$ of $\mathrm{CH}_{2} \mathrm{Cl}_{2}$ solution containing DCC (5.2 g, $25.0 \mathrm{mmol}$ ) dropwise within $15 \mathrm{~min}$. The mixture was slowly warmed to room temperature and stirred for $12 \mathrm{~h}$. The solid was filtered and the filtrate was concentrated, followed by precipitation in cold diethyl ether. After repeated purification by dissolving in $\mathrm{CH}_{2} \mathrm{Cl}_{2}$ and precipitation in cold diethyl ether, $16.7 \mathrm{~g}$ (56.0\% yield) of yellow solid, PEG-CTA, was obtained after drying in vacuo overnight. GPC: $M_{\mathrm{n}}=3800 \mathrm{~g} \mathrm{~mol}^{-1}$, $M_{\mathrm{w}} / M_{\mathrm{n}}=1.02 .{ }^{1} \mathrm{H} \mathrm{NMR}\left(400 \mathrm{MHz}, \mathrm{CDCl}_{3}\right): \delta(\mathrm{ppm}): 0.87(3 \mathrm{H}$, $\left.\mathrm{SCH}_{2} \mathrm{CH}_{2}\left(\mathrm{CH}_{2}\right)_{9} \mathrm{CH}_{3}\right), 1.25\left(18 \mathrm{H}, \mathrm{SCH}_{2} \mathrm{CH}_{2}\left(\mathrm{CH}_{2}\right)_{9} \mathrm{CH}_{3}\right), 1.68$ $\left(2 \mathrm{H}, \mathrm{SCH}_{2} \mathrm{CH}_{2}\left(\mathrm{CH}_{2}\right)_{9} \mathrm{CH}_{3}\right), 1.87\left(3 \mathrm{H}, \mathrm{O}_{2} \mathrm{CCH}_{2} \mathrm{CH}_{2} \mathrm{C}(\mathrm{CN}) \mathrm{CH}_{3}\right)$, 2.36-2.52 (2H, $\left.\mathrm{O}_{2} \mathrm{CCH}_{2} \mathrm{CH}_{2} \mathrm{C}(\mathrm{CN}) \mathrm{CH}_{3}\right), 2.65\left(2 \mathrm{H}, \mathrm{O}_{2} \mathrm{CCH}_{2} \mathrm{CH}_{2} \mathrm{C}\right.$ (CN) $\left.\mathrm{CH}_{3}\right), 3.31\left(2 \mathrm{H}, \mathrm{SCH}_{2} \mathrm{CH}_{2}\left(\mathrm{CH}_{2}\right)_{9} \mathrm{CH}_{3}\right), 3.37\left(3 \mathrm{H}, \mathrm{OCH}_{3}\right)$, 3.45-3.63 (4H, $\left.\mathrm{OCH}_{2} \mathrm{CH}_{2}\right), 3.81\left(2 \mathrm{H}, \mathrm{CO}_{2} \mathrm{CH}_{2} \mathrm{CH}_{2} \mathrm{O}\right), 4.25(2 \mathrm{H}$, $\left.\mathrm{CO}_{2} \mathrm{CH}_{2} \mathrm{CH}_{2} \mathrm{O}\right)$.

\section{RAFT block copolymerization of TF-DEAE-AM mediated by PEG-CTA}

In a typical procedure, AIBN (1.6 mg, $0.01 \mathrm{mmol})$, PEG-CTA (72.3 $\mathrm{mg}, \quad 0.030 \mathrm{mmol}$ trithiocarbonate group), and TF-DEAE-AM $(0.6 \mathrm{~g}, 1.85 \mathrm{mmol})$ were first added to a $25 \mathrm{~mL}$ Schlenk flask (flame-dried under vacuum prior to use) sealed with a rubber septum for degassing and kept under $\mathrm{N}_{2}$. Next, dry THF $(0.6 \mathrm{~mL})$ was charged via a gastight syringe. The flask was degassed by three cycles of freezing-pumping-thawing, followed by immersion of the flask into an oil bath set at $65^{\circ} \mathrm{C}$. The polymerization lasted $48 \mathrm{~h}$ and it was terminated by placing the flask into liquid $\mathrm{N}_{2}$. The reaction mixture was precipitated in diethyl ether. The collected supernatant was then purified by repeated dissolution in THF and precipitation in diethyl ether followed by drying in vacuo overnight to give $0.26 \mathrm{~g}$ of light yellow solid, PEG- $b$-poly(TF-DEAE-AM) 4c. GPC: $M_{\mathrm{n}, \mathrm{GPC}}=8700 \mathrm{~g} \mathrm{~mol}^{-1}\left(M_{\mathrm{n}, \mathrm{NMR}}=11600 \mathrm{~g} \mathrm{~mol}^{-1}\right), M_{\mathrm{w}} / M_{\mathrm{n}}=$ 1.24. FT-IR: $\nu\left(\mathrm{cm}^{-1}\right): 2970,2931,2872,1757,1642,1452,1422$, 1350, 1281, 1147, 976, 845. ${ }^{1} \mathrm{H}$ NMR (400 $\left.\mathrm{MHz} \mathrm{CDCl}_{3}\right): \delta(\mathrm{ppm}):$ $0.88\left(3 \mathrm{H}, \mathrm{SCH}_{2} \mathrm{CH}_{2}\left(\mathrm{CH}_{2}\right)_{9} \mathrm{CH}_{3}\right), 1.00\left(6 \mathrm{H}, \mathrm{CH}_{2} \mathrm{~N}\left(\mathrm{CH}_{2} \mathrm{CH}_{3}\right)_{2}\right), 1.26$ $\left(18 \mathrm{H}, \mathrm{SCH}_{2} \mathrm{CH}_{2}\left(\mathrm{CH}_{2}\right)_{9} \mathrm{CH}_{3}\right), 1.84\left(3 \mathrm{H}, \mathrm{O}_{2} \mathrm{CCH}_{2} \mathrm{CH}_{2} \mathrm{C}(\mathrm{CN}) \mathrm{CH}_{3}\right)$, $1.94\left(2 \mathrm{H}, \mathrm{CH}_{2} \mathrm{CHCON}\right), 2.51\left(1 \mathrm{H}, \mathrm{CH}_{2} \mathrm{CHCON}\right.$ and $6 \mathrm{H}, \mathrm{CH}_{2} \mathrm{~N}$ $\left.\left(\mathrm{CH}_{2} \mathrm{CH}_{3}\right)_{2}\right), \quad 2.69 \quad\left(2 \mathrm{H}, \quad \mathrm{O}_{2} \mathrm{CCH}_{2} \mathrm{CH}_{2} \mathrm{NCH}_{2}\right), \quad 3.30 \quad(4 \mathrm{H}$, $\left.\mathrm{O}_{2} \mathrm{CCH}_{2} \mathrm{CH}_{2} \mathrm{NCH}_{2}\right), 3.38\left(3 \mathrm{H}, \mathrm{OCH}_{3}\right), 3.64\left(\mathrm{OCH}_{2} \mathrm{CH}_{2}\right), 4.21(2 \mathrm{H}$, $\left.\mathrm{CO}_{2} \mathrm{CH}_{2} \mathrm{CH}_{2} \mathrm{O}\right), 4.46\left(2 \mathrm{H}, \mathrm{CO}_{2} \mathrm{CH}_{2} \mathrm{CF}_{3}\right)$.

\section{Micellar morphology}

A THF solution of poly(TF-DEAE-AM) 3b homopolymer or PEG$b$-poly(TF-DEAE-AM) 4b diblock copolymer $\left(10.0 \mathrm{mg} \mathrm{mL}^{-1}\right)$ was added dropwise to distilled water under vigorous stirring and bubbling with $\mathrm{N}_{2}$ until the concentration of the polymer reached $0.5 \mathrm{mg} \mathrm{mL}{ }^{-1}$. THF was evaporated by moderate stirring overnight at room temperature. For TEM studies, $50 \mu \mathrm{L}$ of micelle solution was deposited onto an electron microscopy copper grid coated with carbon film, and the water was evaporated at room temperature.

\section{Titration experiment}

A $50 \mathrm{~mL}$ three-neck round-bottom flask equipped with a Thermo Scientific ${ }^{\mathrm{TM}}$ Orion $^{\mathrm{TM}}$ ROSS Ultra ${ }^{\mathrm{TM}}$ Refillable pH/ATC Triode $^{\mathrm{TM}}$ combination electrode and a Lei-Ci DJS-1C conductance electrode was used to conduct potentiometric titrations. $20 \mathrm{~mL}$ of poly(TF-DEAE-AM) 3b homopolymer $\left(1.0 \mathrm{mg} \mathrm{mL} \mathrm{mL}^{-1}\right)$ in aqueous salt solution $([\mathrm{NaCl}]=10 \mathrm{mM}, \mathrm{pH}=3.0)$ was titrated using a standard $\mathrm{NaOH}$ solution $(1.0 \mathrm{M})$ under constant stirring and bubbling of $\mathrm{N}_{2}$.

\section{Transmittance experiment}

Poly(TF-DEAE-AM) 3b homopolymer was uniformly dispersed in distilled water by ultrasonication until the concentration of the homopolymer reached $0.5 \mathrm{mg} \mathrm{mL}^{-1}$. The gas-based transmittance changes of the aqueous solution were measured using a Hitachi U-2910 spectrophotometer at a constant wavelength of $500 \mathrm{~nm}$.

\section{Determination of critical micelle concentration}

PNA was used as a fluorescence probe to measure the cmc of the PEG- $b$-poly(TF-DEAE-AM) 4 diblock copolymer in the aqueous media. An acetone solution of PNA ([PNA] $=2 \mathrm{mM})$ was added to a large amount of water until the concentration of PNA reached $0.002 \mathrm{mM}$. The solutions for fluorescence measurement were obtained by adding different amounts of THF solutions of PEG- $b$-poly(TF-DEAE-AM) 4 diblock copolymer $\left(1,0.1,0.01,0.001\right.$, or $\left.0.0001 \mathrm{mg} \mathrm{mL}^{-1}\right)$ to water containing PNA $([\mathrm{PNA}]=0.002 \mathrm{mM})$. THF was evaporated by constant 
stirring and bubbling $\mathrm{N}_{2}$ overnight at room temperature. The solution was sealed in vials prior to measurement to avoid the influence of $\mathrm{CO}_{2}$ or $\mathrm{O}_{2}$ present in air.

\section{Results and discussion}

Design and synthesis of TF-DEAE-AM trifunctional acrylamide monomer

Given the well-studied $\mathrm{CO}_{2}$-responsive PDEAEMA ${ }^{24}$ and $\mathrm{O}_{2}$-responsive PTFMA, ${ }^{26,27}$ we attempted to incorporate DEAE and 2,2,2-trifluoroethyl (TF) functional groups into a single monomer, and utilize RAFT polymerization to construct dualgas-stimulus responsive polymers. The key in the preparation of the target monomer is to incorporate a polymerizable group, DEAE group, and TF group within a monomer. Our group designed a two-step strategy to connect two different temperature- and $\mathrm{pH}$-responsive groups and acrylamide group together. ${ }^{40,41}$ This strategy possesses several advantages, such as facile sample preparation and possibility to accomplish multifunctional materials, and great opportunities to enlarge the applications of this type of polymer. Inspired by the study, we employed a similar strategy in the current study by applying aza-Michael reaction as a key approach to provide the target secondary amine (TF-DEAE) intermediate in a single step, which could be utilized in a further reaction to afford a polymerizable acrylamide monomer (TF-DEAE-AM).

The key intermediate of 2,2,2-trifluoroethyl 3-(2-(diethylamino)ethylamino)-propanoate $\mathbf{1}$ secondary amine was first prepared through aza-Michael addition reaction using 2,2,2-trifluoroethyl acrylate and $N, N$-diethylethylenediamine. ${ }^{1} \mathrm{H},{ }^{13} \mathrm{C}$, and ${ }^{19} \mathrm{~F}$ NMR spectra, shown in Fig. $\mathrm{S} 1, \uparrow$ display the expected resonance signals of the target compound, which confirm the chemical structure of the target intermediate, i.e. TF-DEAE 1. Subsequently, TF-DEAE 1 was treated with acryloyl chloride to afford the desired TF-DEAE-AM 2 acrylamide monomer. The chemical structure of TF-DEAE-AM 2 monomer was characterized via ${ }^{1} \mathrm{H}$ NMR, ${ }^{13} \mathrm{C}$ NMR, ${ }^{19} \mathrm{~F}$ NMR, HR-MS, FT-IR, and EA in detail. Fig. 1A shows ${ }^{1} \mathrm{H}$ NMR spectrum of the monomer, which exhibits typical proton resonance signals of a double bond at 6.54, 6.32, and $5.68 \mathrm{ppm}$ (peaks "a" and "b"), 2,2,2-trifluoroethyl unit at $4.44 \mathrm{ppm}$ (peak "c"), and DEAE moiety at 0.99 ppm (peak "i”). The ${ }^{13} \mathrm{C}$ NMR spectrum (Fig. 1B) displays the expected resonance signals of carbonyls at 166.6 and 170.7 ppm (peaks "c" and "f") and double bond at 121.6 and 124.4 ppm (peaks "a" and "b"), respectively. The only resonance signal located at $-73.8 \mathrm{ppm}$ in the ${ }^{19} \mathrm{~F}$ NMR spectrum (Fig. 1C) was attributed to fluorine atoms in $-\mathrm{C} F_{3}$, this verified the existence of TF unit. Furthermore, HR-MS result (325.1732) was also consistent well with the theoretical value $\left(\mathrm{C}_{14} \mathrm{H}_{24} \mathrm{~N}_{2} \mathrm{O}_{3} \mathrm{~F}_{3}, 325.1734\right)$. All these results clearly confirmed the structure of the acrylamide monomer TF-DEAE-AM 2.

\section{Synthesis of poly(TF-DEAE-AM) homopolymer}

In the present study, RAFT polymerization ${ }^{43-47}$ was chosen for the synthesis of poly(TF-DEAE-AM) 3 homopolymer since
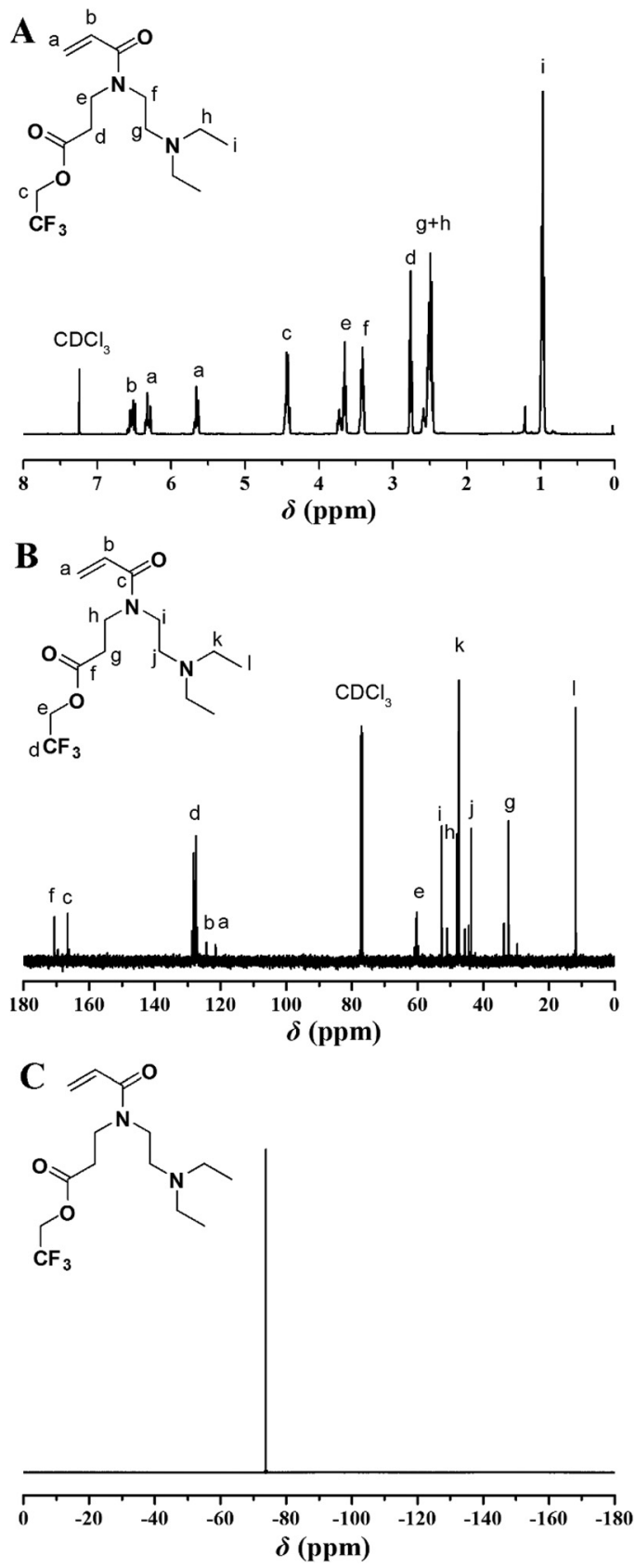

Fig. $1{ }^{1} \mathrm{H}(\mathrm{A}),{ }^{13} \mathrm{C}(\mathrm{B})$, and ${ }^{19} \mathrm{~F}$ (C) NMR spectra of TF-DEAE-AM 2 in $\mathrm{CDCl}_{3}$.

RAFT polymerization is one of the most powerful and versatile reversible degenerative radical polymerization (RDRP) processes that ensures precise control over molecular weight and molecular weight distribution in mild reaction conditions. Two poly(TF-DEAE-AM) 3 homopolymers were prepared by varying the feeding ratio of TF-DEAE-AM 2 monomer to CTA of CDSTSP $(30: 1$ and $50: 1)$ and reaction time, as listed in Table 1.

Both homopolymers show symmetric and unimodal eluent peaks in their GPC curves (Fig. 2A) with relatively narrow molecular weight distributions $\left(M_{\mathrm{w}} / M_{\mathrm{n}}<1.40\right)$, which are indicative 
Table 1 Synthesis of poly(TF-DEAE-AM) 3 by RAFT homopolymerization $^{a}$

\begin{tabular}{|c|c|c|c|c|c|c|}
\hline Sample & {$[2]:[\mathrm{CTA}]$} & $\begin{array}{l}\text { Time } \\
\text { (h) }\end{array}$ & $\begin{array}{l}\text { Conv. }{ }^{b} \\
(\%)\end{array}$ & $\begin{array}{l}M_{\mathrm{n}, \text { Theo }}{ }^{c} \\
\left(\mathrm{~g} \mathrm{~mol}^{-1}\right)\end{array}$ & $\begin{array}{l}M_{\mathrm{n}}{ }^{d} \\
\left(\mathrm{~g} \mathrm{~mol}^{-1}\right)\end{array}$ & $M_{\mathrm{w}} / M_{\mathrm{n}}{ }^{d}$ \\
\hline $3 a$ & $30: 1$ & 12 & 80.5 & 8236 & 5500 & 1.29 \\
\hline $3 b$ & $50: 1$ & 15 & 78.3 & 13101 & 10500 & 1.36 \\
\hline
\end{tabular}

${ }^{a}[\mathrm{AIBN}]:[\mathrm{CTA}]=1: 3$, solvent: THF, temperature: $65^{\circ} \mathrm{C} .{ }^{b}$ Measured by ${ }^{1} \mathrm{H}$ NMR. ${ }^{c} M_{\mathrm{n}, \text { Theo }}=M_{\mathrm{n}, 2} \times([2]:[\mathrm{CTA}]) \times$ conversion $+M_{\mathrm{n}, \mathrm{CTA}}$. ${ }^{d}$ Measured by GPC in THF at $35^{\circ} \mathrm{C}$.
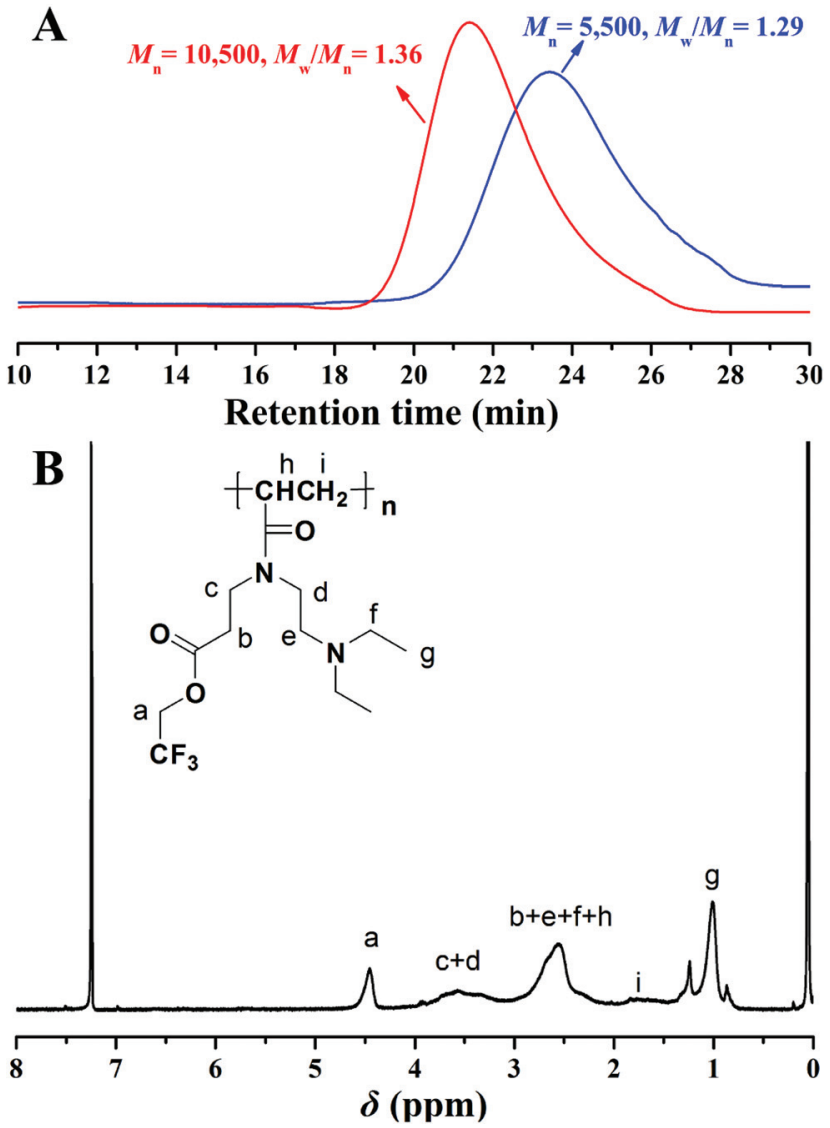

Fig. 2 (A) GPC traces of poly(TF-DEAE-AM) 3 homopolymer in THF; and (B) ${ }^{1} \mathrm{H}$ NMR spectrum of poly(TF-DEAE-AM) 3 homopolymer in $\mathrm{CDCl}_{3}$.

of the good choice of CDSTSP as CTA for mediating the polymerization and well-defined structure of the obtained poly (TF-DEAE-AM) 3 homopolymer. The molecular weights of the homopolymers measured by GPC are smaller than theoretical values due to the difference in the structure of poly (TF-DEAE-AM) 3 homopolymer and PMMA standards. A typical ${ }^{1} \mathrm{H}$ NMR spectrum of poly(TF-DEAE-AM) 3 homopolymer is shown in Fig. 2B, which shows the disappearance of the proton resonance signals of the double bond and the retention of the peaks of TF moiety (peak "a") and DEAE unit (peak "g"). These observations affirmed the chemical structure of poly(TF-DEAE-AM) 3 homopolymer.

\section{Solution behavior of poly(TF-DEAE-AM) homopolymer}

As a type of weak polybase, PDEAEMA homopolymer is soluble in water as a weak cationic polyelectrolyte in acidic surroundings due to the protonation of its tertiary amine group; however, it becomes insoluble at room temperature in a neutral or basic environment. The $\mathrm{p} K_{\mathrm{a}}$ of its conjugated acid is about 7.3. ${ }^{4-51}$ Although it is expected that poly (TF-DEAE-AM) 3 homopolymer should have similar $\mathrm{pH}$ stimulus responsiveness as PDEAEMA, the difference in their chemical structure might result in a change in $\mathrm{p} K_{\mathrm{a}}$ of the conjugated acid of DEAE group. In order to measure the degree of protonation of DEAE group on $\mathrm{pH}$ of aqueous solution, $\mathrm{pH}$ value and conductivity of an aqueous solution of poly(TF-DEAE-AM) 3b homopolymer were measured at the same time by adding $\mathrm{NaOH}$ solution $(1.0 \mathrm{M})$ to the acidic poly(TF-DEAE-AM) $3 \mathbf{b}$ solution according to the previous report. ${ }^{52}$

As shown in Fig. 3A, three regions can be divided on the basis of the changes in $\mathrm{pH}$ and conductivity, in which the second region between the two transition points (point a, $\mathrm{pH}$ $\sim 4.7$ and point $\mathrm{b}, \mathrm{pH} \sim 8.4$ ) corresponds to the deprotonation process of $\mathrm{NH}^{+}\left(\mathrm{C}_{2} \mathrm{H}_{5}\right)_{2}$ group from the fully protonated state to the unionized state. We define that the degree of protonation of DEAE group is $100 \%$ when the $\mathrm{pH}$ of the solution is 4.7 ,
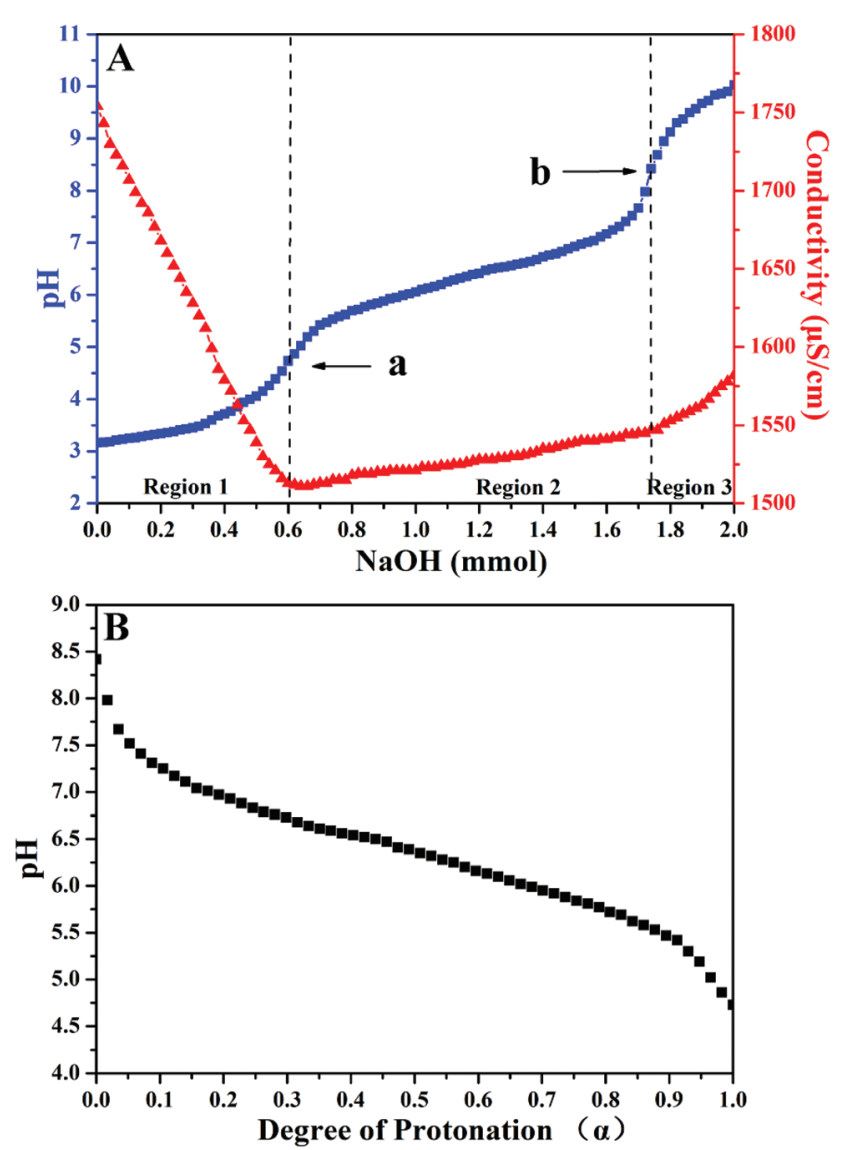

Fig. 3 (A) Titration curves of poly(TF-DEAE-AM) 3b homopolymer $\left(1.0 \mathrm{mg} \mathrm{mL}^{-1}\right.$ ) at $25^{\circ} \mathrm{C}$ in $10 \mathrm{mM} \mathrm{NaCl}$; and (B) profile for the dependence of protonation on $\mathrm{pH}$. 
and the degree of protonation of DEAE group is $0 \%$ when $\mathrm{pH}$ of the solution is 8.4. Based on this information, we obtained the profile of the dependence of degree of protonation of DEAE group with $\mathrm{pH}$ (Fig. 3B). The $\mathrm{pH}$ value of a saturated $\mathrm{CO}_{2}$ aqueous solution is about 3.9 at room temperature and atmosphere pressure so that $100 \%$ of tertiary amino of poly (TF-DEAE-AM) 3 homopolymer would be protonated by carbonic acid under this condition. ${ }^{20-24}$ As a result, it can be expected that poly(TF-DEAE-AM) 3 homopolymer will exhibit $\mathrm{CO}_{2}$-responsive behavior in an aqueous solution.

The transmittance results of poly(TF-DEAE-AM) $3 \mathbf{b}$ aqueous solution at room temperature in response to $\mathrm{CO}_{2}$ are shown in Fig. 4 and it was found that a turbid solution was well observed at $25{ }^{\circ} \mathrm{C}$ (Fig. 4A) before treatment with $\mathrm{CO}_{2}(10 \mathrm{~mL}$ $\left.\min ^{-1}\right)$. The solution became entirely transparent after the injection of $\mathrm{CO}_{2}$, while $\mathrm{pH}$ decreased from 8.0 to 4.7 due to the complete protonation of the tertiary amine group. The zetapotential of the solution containing poly(TF-DEAE-AM) $\mathbf{3 b}$ aggregates greatly increased from $15.5 \mathrm{mV}$ to $47.5 \mathrm{mV}$ after the injection of $\mathrm{CO}_{2}$, which indicates that the protonated DEAE chains indeed formed a new corona with positive charges.

Subsequently, after passing $\mathrm{N}_{2}\left(10 \mathrm{~mL} \mathrm{~min}^{-1}\right)$ through the solution to remove $\mathrm{CO}_{2}$, a sharp drop in transmittance was observed (Fig. 4B) because of the deprotonation of DEAE group. Repeatable cycles under alternating $\mathrm{CO}_{2} / \mathrm{N}_{2}$ stimulation (Fig. 4B) indicated the $\mathrm{CO}_{2}$-responsive reversibility of poly (TF-DEAE-AM) 3 homopolymer. Since the removal of $\mathrm{CO}_{2}$ by $\mathrm{N}_{2}$ in aqueous solution represents a physical process, it needs enough time to completely recover. However, considering that a rather long time purging would lead to an evident loss of water, we herein set a consistent time of $1 \mathrm{~h}$ to bubble the gas, and thus, an apparent difference in turbidity was observed during the process of deprotonation.

In order to gain deep insight into the solubility of poly (TF-DEAE-AM) 3 homopolymer in aqueous solution upon bubbling $\mathrm{CO}_{2},{ }^{1} \mathrm{H}$ and ${ }^{19} \mathrm{~F}$ NMR spectra of poly(TF-DEAE-AM) $3 \mathbf{b}$ in $\mathrm{D}_{2} \mathrm{O}$ before and after bubbling gas were recorded. Before bubbling $\mathrm{CO}_{2}$, no signal was found in both ${ }^{1} \mathrm{H}$ and ${ }^{19} \mathrm{~F}$ NMR spectra (green line in Fig. $4 \mathrm{C}$ and D). In $\mathrm{CO}_{2}$-saturated $\mathrm{D}_{2} \mathrm{O}$, however, the characteristic signals of DEAE group attributed to the protons of "a", "b" and "c" appear at 1.12 and 3.02 ppm, respectively, which is indicative of the good solubility of tertiary amine groups (red line in Fig. 4C). On the other hand, ${ }^{19} \mathrm{~F}$ NMR spectrum exhibits a weak and broad signal centered at -74.1 ppm after treatment with $\mathrm{CO}_{2}$ (red line in Fig. 4D), which suggests that TF groups are also partly soluble due to the increase in solubility of the close protonated DEAE groups after bubbling $\mathrm{CO}_{2}$. After the removal of $\mathrm{CO}_{2}$ by $\mathrm{N}_{2}$, the two typical signals of DEAE group in ${ }^{1} \mathrm{H}$ NMR spectrum and characteristic peak originating from $\mathrm{TF}$ moiety in ${ }^{19} \mathrm{~F}$ NMR spectrum disappear again because of the deprotonation of DEAE group (blue line in Fig. 4C and D). Moreover, the protonation/deprotonation process could be reproduced over several cycles. It is believed that the interactions between $\mathrm{CO}_{2}$ and DEAE groups increased the solubility of poly(TF-DEAE-AM). In comparison with the chemical process of protonation by $\mathrm{CO}_{2}$, van der Waals interactions between $\mathrm{O}_{2}$ and $\mathrm{C}-\mathrm{F}$ bonds appeared to be too weak, and there was no significant change in both transmittance and NMR spectrum after $\mathrm{O}_{2}$ treatment (10 $\left.\mathrm{mL} \mathrm{min}^{-1}\right)$.

We then utilized DLS and TEM to examine the size and morphology of the aggregates formed by poly(TF-DEAE-AM) $\mathbf{3 b}$
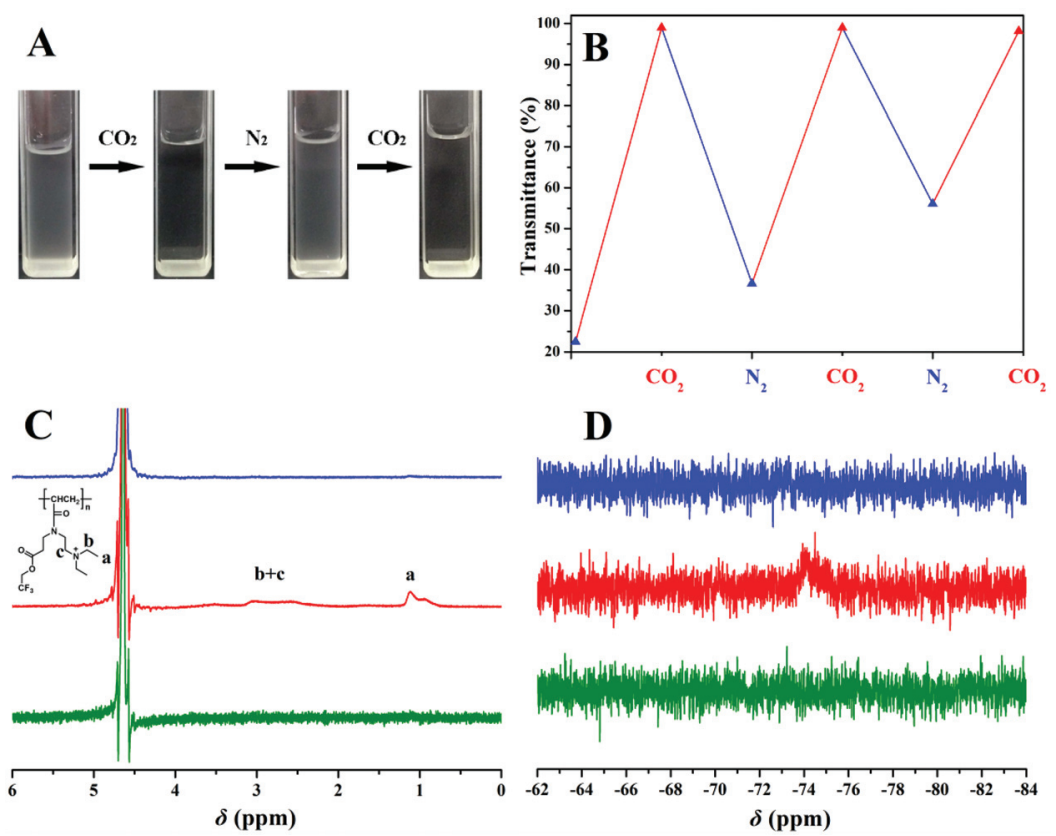

D

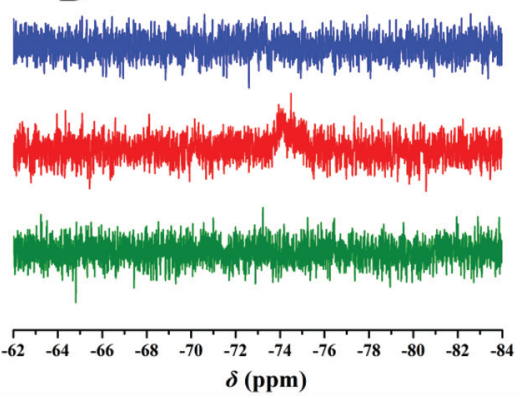

Fig. 4 Optical images (A) and transmittance changes (B) of poly(TF-DEAE-AM) 3b aqueous solution $\left(0.5 \mathrm{mg} \mathrm{mL}^{-1}\right)$ with $\mathrm{CO}_{2} / \mathrm{N}_{2}$ gas triggers; and ${ }^{1} \mathrm{H}$ (C) and ${ }^{19} \mathrm{~F}$ (D) NMR spectra of poly(TF-DEAE-AM) $3 \mathrm{~b}$ in $\mathrm{D}_{2} \mathrm{O}$ before (green) and after $\mathrm{CO}_{2}$ (red) or $\mathrm{CO}_{2} / \mathrm{N}_{2}$ (blue) treatment. 
homopolymer upon the treatment of $\mathrm{N}_{2}, \mathrm{O}_{2}$, and $\mathrm{CO}_{2}$, respectively. The micellar solution of poly(TF-DEAE-AM) 3b homopolymer was prepared by adding $0.5 \mathrm{~mL}$ of THF solution of poly(TF-DEAE-AM) $\mathbf{3 b}$ homopolymer $\left(10 \mathrm{mg} \mathrm{mL}^{-1}\right)$ in $10 \mathrm{~mL}$ of water, followed by removing THF by stirring and bubbling of $\mathrm{N}_{2}$ at room temperature over $24 \mathrm{~h}$. Two additional aliquots $(3.0 \mathrm{~mL})$ taken from the micellar solution were treated with $\mathrm{CO}_{2}$ and $\mathrm{O}_{2}$, respectively.

As shown in Fig. 5A, spindle-shaped aggregates with an average hydrodynamic diameter of $379 \mathrm{~nm}$ (green line in Fig. 5D) were formed in aqueous media with the bubbling of $\mathrm{N}_{2}$. After the solution was bubbled with $\mathrm{O}_{2}$ for $1 \mathrm{~h}$, interestingly, only spherical aggregates (Fig. 5B) with an average hydrodynamic diameter of $234 \mathrm{~nm}$ (red line in Fig. 5D), clearly smaller than that without the treatment with $\mathrm{O}_{2}$, were observed. This phenomenon might indicate that the large spindle-shaped aggregates fell apart and formed spherical aggregates. Although we cannot observe noticeable changes in the solubility, and ${ }^{1} \mathrm{H}$ and ${ }^{19} \mathrm{~F}$ NMR spectra of poly (TF-DEAE-AM) 3b homopolymer upon bubbling $\mathrm{O}_{2}$, this evident change in morphology of aggregates clearly demonstrates the $\mathrm{O}_{2}$-stimulus responsiveness of poly(TF-DEAE-AM) 3 homopolymer. Similarly, the spindle-shaped aggregates also changed into ill-defined spherical micelles (Fig. 5C) with an average hydrodynamic diameter of $327 \mathrm{~nm}$ (blue line in Fig. 5D) after bubbling $\mathrm{CO}_{2}$ for $1 \mathrm{~h}$. Different from the spherical micelles observed after the treatment with $\mathrm{O}_{2}$, there were several isolated darker "dots" in the matrix of the aggregates.
This observation suggests that the aggregates composed of these darker dots are formed by poly(TF-DEAE-AM) 3 homopolymer.

\section{Synthesis of PEG- $b$-poly(TF-DEAE-AM) diblock copolymer}

Although poly(TF-DEAE-AM) 3 homopolymer has both $\mathrm{CO}_{2}$ and $\mathrm{O}_{2}$-stimuli responsiveness, the homopolymer is completely insoluble in physiological environment and as a result, its applications in the biomedical field would be limited. It is necessary to connect poly(TF-DEAE-AM) with a hydrophilic and biocompatible segment for the construction of potential intelligent drug delivery systems, in which the release of hydrophobic drugs loaded in the core of aggregates formed by poly(TF-DEAE-AM) segment could be tuned as a response to $\mathrm{CO}_{2}$ and $\mathrm{O}_{2}$. In the current study, we selected PEG as the hydrophilic segment due to its unique biocompatibility and broad application in biomedicine. ${ }^{53-56}$

A PEG-based macro-CTA (PEG-CTA) was first prepared via the attachment of the acidic functional trithiocarbonate of CDSTSP to PEG-OH $\left(M_{\mathrm{n}}=2000 \mathrm{~g} \mathrm{~mol}^{-1}\right)$ following a commonly-used procedure. ${ }^{57-60}{ }^{1} \mathrm{H}$ NMR spectrum of PEG-CTA (Fig. S2 $\dagger$ ) exhibits the attachment of CDSTSP onto the chain end of PEG. Then, PEG- $b$-poly(TF-DEAE-AM) 4 diblock copolymers were obtained by RAFT polymerization of TF-DEAE-AM 2 using PEG-CTA as the chain transfer agent. By varying the polymerization time and feeding ratio of monomer 2 to PEG-CTA, three PEG- $b$-poly(TF-DEAE-AM) 4 diblock copolymers

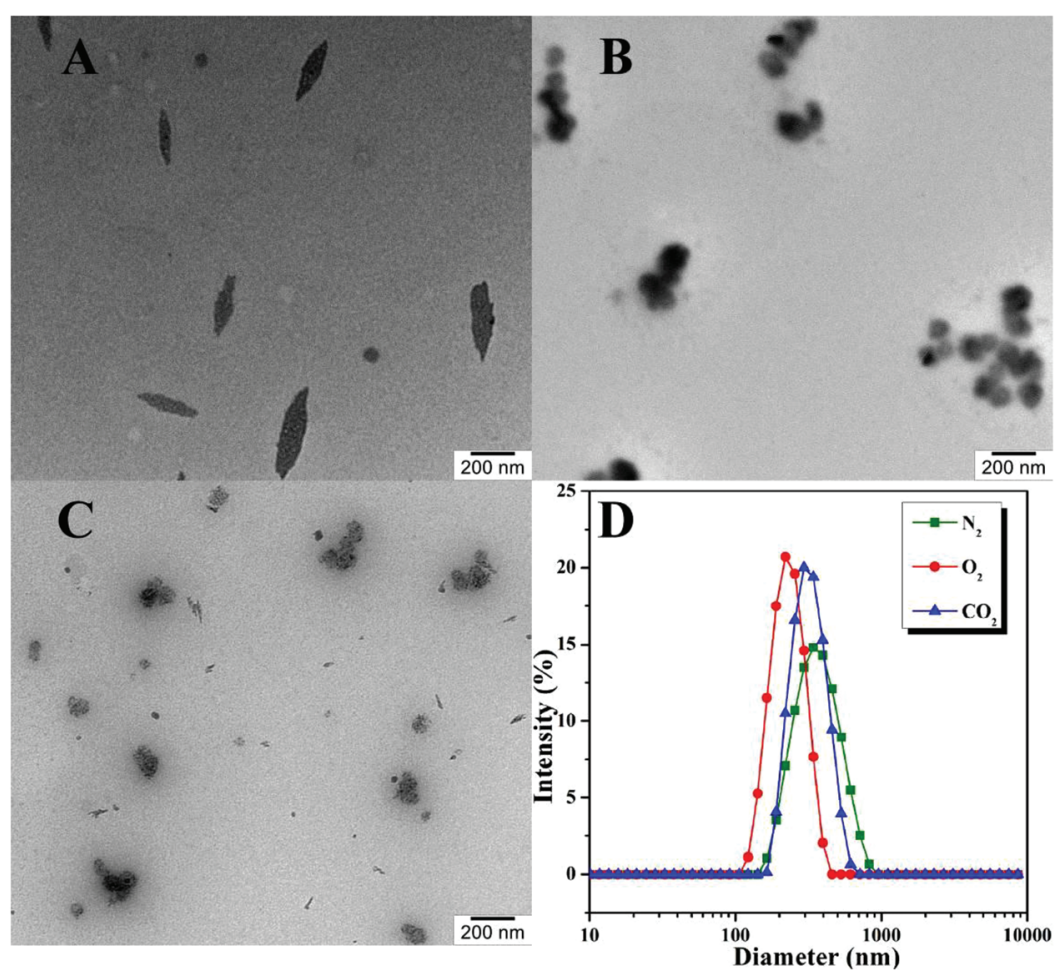

Fig. 5 TEM images of poly(TF-DEAE-AM) 3b after $\mathrm{N}_{2}$ (A), $\mathrm{O}_{2}(\mathrm{~B})$, and $\mathrm{CO}_{2}$ (C) treatment and the corresponding hydrodynamic diameter distributions (D). 
Table 2 Synthesis of PEG- $b$-poly(TF-DEAE-AM) 4 by RAFT polymerization ${ }^{a}$

\begin{tabular}{llllllllll}
\hline Sample & {$[2]:[\mathrm{CTA}]$} & Time $(\mathrm{h})$ & Conv. $^{b}(\%)$ & $M_{\mathrm{n}, \mathrm{NMR}^{c}}{ }^{c}\left(\mathrm{~g} \mathrm{~mol}^{-1}\right)$ & $M_{\mathrm{n}, \mathrm{Theo}}{ }^{d}\left(\mathrm{~g} \mathrm{~mol}^{-1}\right)$ & $M_{\mathrm{n}, \mathrm{GPC}}{ }^{e}\left(\mathrm{~g} \mathrm{~mol}^{-1}\right)$ & $M_{\mathrm{w}} / M_{\mathrm{n}}{ }^{e}$ & $f^{f}$ & $\mathrm{cmc}^{g}\left(\mathrm{~g} \mathrm{~mL}^{-1}\right)$ \\
\hline 4a & $30: 1$ & 12 & 67.9 & 4200 & 8991 & 5800 & 1.13 & 0.43 & $6.8 \times 10^{-5}$ \\
4b & $30: 1$ & 60 & 98.6 & 8900 & 11978 & 6700 & 1.11 & 0.73 & $1.8 \times 10^{-5}$ \\
4c & $60: 1$ & 48 & 95.0 & 11600 & 20872 & 8700 & 1.24 & 0.79 & $8.3 \times 10^{-6}$
\end{tabular}

${ }^{a}[\mathrm{AIBN}]:[\mathrm{CTA}]=1: 3$, solvent: THF, temperature: $65{ }^{\circ} \mathrm{C} .{ }^{b}$ Measured by ${ }^{1} \mathrm{H}$ NMR. ${ }^{c}$ Obtained from ${ }^{1} \mathrm{H}$ NMR. ${ }^{d} M_{\mathrm{n}, \mathrm{Theo}}=M_{\mathrm{n}, 2} \times([2]:[\mathrm{CTA}]) \times$ conv. + $M_{\mathrm{n}, \mathrm{CTA}} \cdot{ }^{e}$ Measured by GPC in THF at $35^{\circ} \mathrm{C} .{ }^{f}$ Weight fraction of hydrophobic poly(TF-DEAE-AM) segment in copolymer $4 .{ }^{g}$ Determined by fluorescence spectroscopy using PNA as the probe.

with different chain lengths of poly(TF-DEAE-AM) were prepared, as summarized in Table 2.

Fig. 6A shows the GPC traces of the PEG-CTA and PEG- $b$ poly(TF-DEAE-AM) 4 diblock copolymer. Compared to PEG-CTA, the elution time of the PEG- $b$-poly(TF-DEAE-AM) 4 diblock polymers decreased with an increase in polymerization time and feeding ratio of monomer 2 to PEG-CTA, indicating the extension of the polymer chain of poly(TF-DEAE-AM) from PEG-CTA. In addition, unimodal and symmetrical elution peaks with narrow molecular weight distributions $\left(M_{\mathrm{w}} / M_{\mathrm{n}} \leq 1.24\right)$
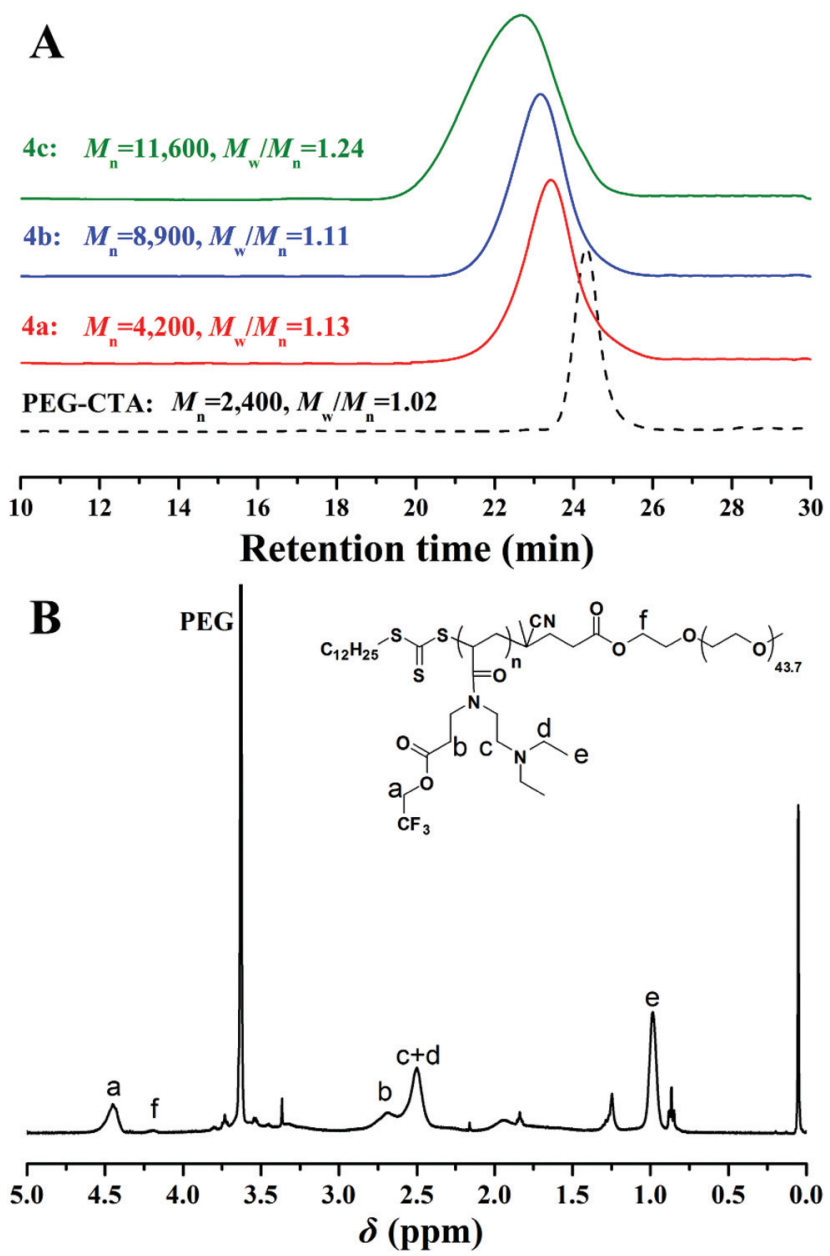

Fig. 6 (A) GPC traces of PEG- $b$-poly(TF-DEAE-AM) 4 diblock copolymer in THF $\left(M_{n}\right.$ was obtained from ${ }^{1} \mathrm{H}$ NMR in $\left.\mathrm{CDCl}_{3}\right)$; and (B) ${ }^{1} \mathrm{H}$ NMR spectrum of PEG-b-poly(TF-DEAE-AM) 4 diblock copolymer in $\mathrm{CDCl}_{3}$. were observed for PEG- $b$-poly(TF-DEAE-AM) 4 diblock polymers. The chemical structure of PEG- $b$-poly(TF-DEAE-AM) 4 diblock polymer was characterized via ${ }^{1} \mathrm{H}$ NMR observations (Fig. 6B). The typical proton resonance signals originating from PEG block (3.64 ppm) still appear in ${ }^{1} \mathrm{H}$ NMR spectrum. The peak "a" located at $4.46 \mathrm{ppm}$ is attributed to two protons of $\mathrm{CO}_{2} \mathrm{CH}_{2} \mathrm{CF}_{3}$ moiety in TF-DEAE-AM repeated unit, whereas the peak " $\mathrm{f}$ " located at $4.21 \mathrm{ppm}$ corresponds to two protons of $\mathrm{CO}_{2} \mathrm{CH}_{2} \mathrm{CH}_{2} \mathrm{O}$ linkage between poly(TF-DEAE-AM) and PEG in the main chain. On the basis of these results and chain length of PEG, the "absolute" molecular weight of PEG- $b$-poly (TF-DEAE-AM) 4 diblock copolymer could be calculated by ${ }^{1} \mathrm{H}$ NMR observations according to eqn $(1)\left(S_{\mathrm{a}}\right.$ and $S_{\mathrm{f}}$ are integral areas of peak "a" and "f" in Fig. 6B, respectively; and 325 and 2385 are the molecular weights of monomer 2 and PEG-CTA, respectively). Since the chemical structure of PEG- $b$ poly(TF-DEAE-AM) $\mathbf{4}$ diblock copolymer is different from PMMA standards, the molecular weights obtained from ${ }^{1} \mathrm{H}$ NMR analysis were employed in the current study, which are indeed very different from those obtained from GPC. As listed in Table 2, three different PEG- $b$-poly(TF-DEAE-AM) 4 diblock copolymers with 6,20 , and 29 TF-DEAE-AM repeated units were prepared in the current case.

$$
M_{\mathrm{n}}=325\left(S_{\mathrm{a}} / S_{\mathrm{f}}\right)+2385
$$

\section{Solution behavior of PEG-b-poly(TF-DEAE-AM) diblock copolymer}

The critical micelle concentration $(\mathrm{cmc})$ of the amphiphilic PEG$b$-poly(TF-DEAE-AM) 4 diblock polymer in aqueous solution without external stimuli was firstly determined via fluorescence spectroscopy using PNA as the fluorescence probe. ${ }^{61}$ The fluorescence intensity of PNA is sensitive to the environment and the polarity of its surroundings and it could be easily quenched by polar solvents such as water. ${ }^{61}$ Once micelles are formed in aqueous solution, the hydrophobic PNA could be encapsulated into their hydrophobic core, and thus, the value of $I / I_{0}$ would dramatically increase ( $I$ and $I_{0}$ refer to the fluorescence intensities of PNA at $418 \mathrm{~nm}$ with and without PEG- $b$-poly (TF-DEAE-AM) in aqueous solution, respectively). ${ }^{61}$ The relationships of $I / I_{0}$ of PNA as a function of the concentration of PEG- $b$ poly(TF-DEAE-AM) 4 diblock polymer are plotted in Fig. 7. It is clear that when the concentration of copolymer 4 exceeds a certain value, $I / I_{0}$ increases sharply due to the transferring of PNA probe into the hydrophobic core region of the micelles. 

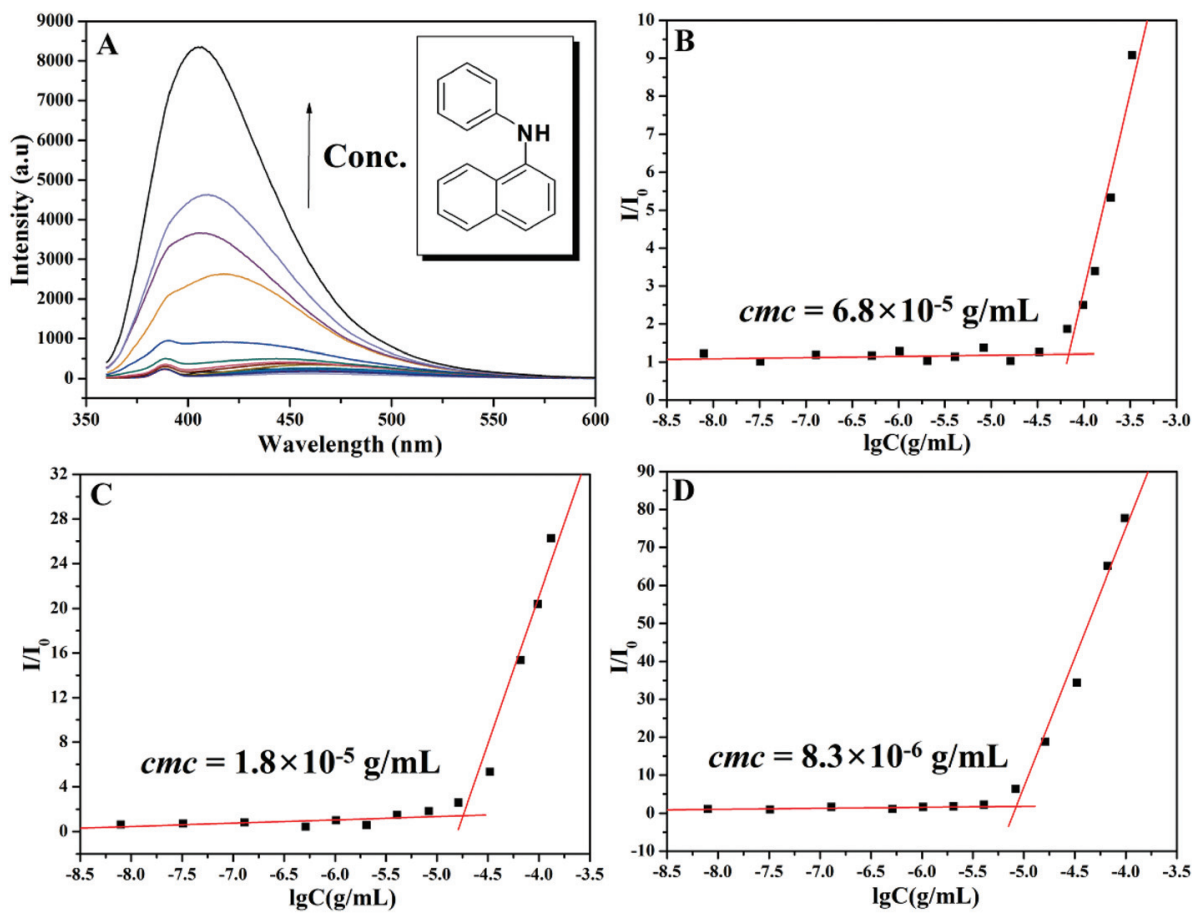

Fig. 7 (A) Fluorescence emission spectra of PNA $(0.002 \mathrm{mM})$ in an aqueous solution of PEG- $b$-poly(TF-DEAE-AM) 4 diblock copolymer. Dependence of the fluorescence intensity $\left(I / I_{0}\right)$ of the PNA emission band at $418 \mathrm{~nm}$ on the concentration of PEG- $b$-poly(TF-DEAE-AM) $4 a$ (B), $4 \mathrm{~b}$ (C), and 4c (D) diblock polymers.

Thus, the $c m c$ of PEG- $b$-poly(TF-DEAE-AM) 4 diblock copolymer was determined to be the intersection of two straight lines and the results are summarized in Table 2. The $c m c$ of PEG-b-poly (TF-DEAE-AM) 4 diblock copolymer increased from $8.3 \times 10^{-6} \mathrm{~g}$ $\mathrm{mL}^{-1}$ to $6.8 \times 10^{-5} \mathrm{~g} \mathrm{~mL}^{-1}$ with a decrease in the chain length of poly(TF-DEAE-AM) block, which is consistent with a previous report. ${ }^{62}$

The potentiometric and conductometric titration of PEG- $b$ poly(TF-DEAE-AM) 4b diblock copolymer (Fig. S3†) illustrates that the degree of protonation of DEAE groups was $100 \%$ when the $\mathrm{pH}$ of the solution was 4.7 , whereas the degree of protonation was $0 \%$ when the $\mathrm{pH}$ of the solution was 8.7. We then examined the $\mathrm{CO}_{2}$ and $\mathrm{O}_{2}$-stimuli response behaviors of the micelles formed by PEG- $b$-poly(TF-DEAE-AM) 4 diblock copolymer. $0.5 \mathrm{~mL}$ of THF solution of PEG- $b$-poly(TF-DEAE-AM) $\mathbf{4 b}$ diblock copolymer $\left(10 \mathrm{mg} \mathrm{mL}^{-1}\right)$ was added to $10 \mathrm{~mL}$ of water with stirring and bubbling of $\mathrm{N}_{2}\left(10 \mathrm{~mL} \mathrm{~min}^{-1}\right)$. THF was then removed via evaporation with stirring and bubbling of $\mathrm{N}_{2}$ at room temperature over $24 \mathrm{~h}$. Two additional aliquots $(3.0 \mathrm{~mL})$ taken from the micellar solution were treated with $\mathrm{CO}_{2}$ and $\mathrm{O}_{2}$, separately. PEG- $b$-poly(TF-DEAE-AM) 4b diblock copolymer formed spherical aggregates (Fig. $8 \mathrm{~B}$ ) with a $D_{\mathrm{h}}$ of $140 \mathrm{~nm}$ (green line in Fig. 8A). Upon bubbling $\mathrm{CO}_{2}\left(10 \mathrm{mg} \mathrm{mL} \mathrm{m}^{-1}\right)$ for $1 \mathrm{~h}$, the aggregates were still spherical (Fig. 8D), although the size of the aggregates increased from $140 \mathrm{~nm}$ to $191 \mathrm{~nm}$ (blue line in Fig. 8A). The surface of the aggregates became more smooth (Fig. 8D) compared to the aggregates without bubbling $\mathrm{CO}_{2}$ (Fig. 8B). The zeta potential of the solution containing
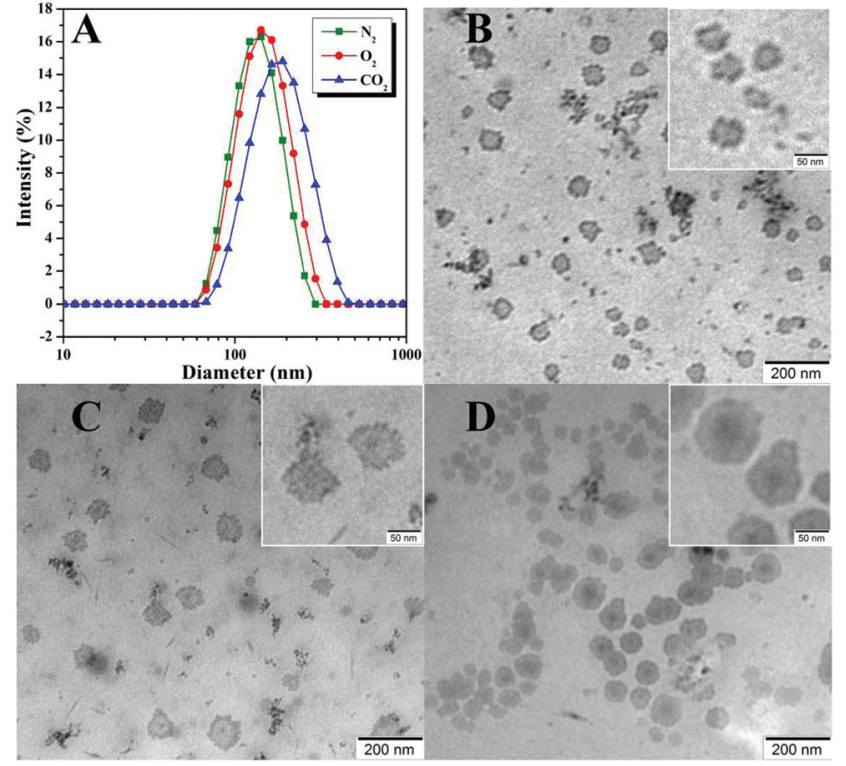

Fig. 8 Hydrodynamic diameter distributions (A) and TEM images of PEG- $b$-poly(TF-DEAE-AM) 4b diblock copolymer in aqueous solution after treatment with $\mathrm{N}_{2}(\mathrm{~B}), \mathrm{O}_{2}(\mathrm{C})$, and $\mathrm{CO}_{2}$ (D).

PEG- $b$-poly(TF-DEAE-AM) $4 \mathbf{b}$ aggregates greatly increased from $9.8 \mathrm{mV}$ to $20.9 \mathrm{mV}$ after $\mathrm{CO}_{2}$ was injected, which demonstrates that DEAE groups were protonated to $\mathrm{DEAE}^{+}$in order to be extruded out from the core to form a new corona. Fig. 9 shows 


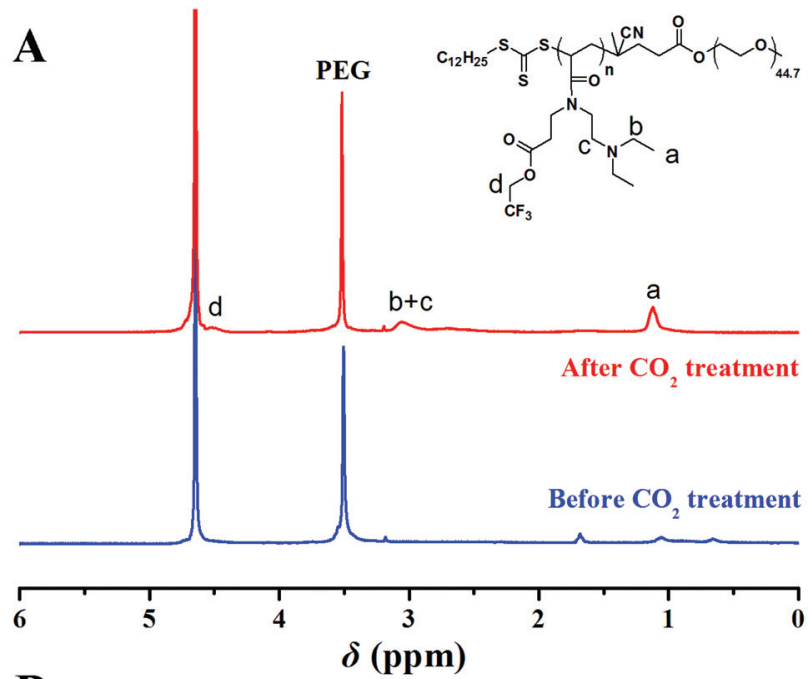

B

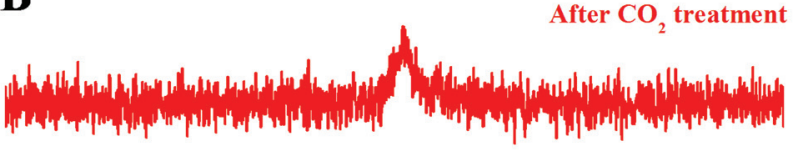

Before $\mathrm{CO}_{2}$ treatment
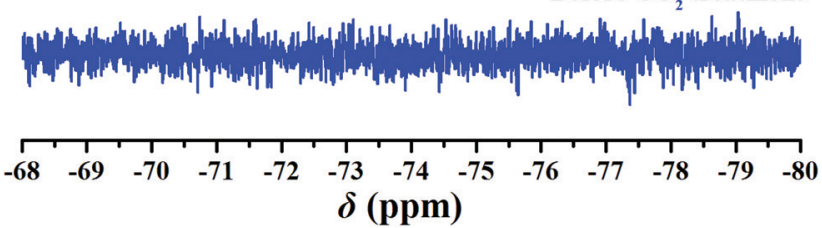

Fig. $9{ }^{1} \mathrm{H}(\mathrm{A})$ and ${ }^{19} \mathrm{~F}$ (B) NMR spectra of PEG-b-poly(TF-DEAE-AM) 4b diblock copolymer in $\mathrm{D}_{2} \mathrm{O}$ before (blue) and after (red) $\mathrm{CO}_{2}$ treatment.

${ }^{1} \mathrm{H}$ and ${ }^{19} \mathrm{~F}$ NMR spectra of PEG- $b$-poly(TF-DEAE-AM) 4b diblock copolymer in $\mathrm{D}_{2} \mathrm{O}$ treated with $\mathrm{N}_{2}$ and $\mathrm{CO}_{2}$, respectively. The typical peak at $3.64 \mathrm{ppm}$ corresponding to four protons of the PEG segment could be observed upon the treatment of $\mathrm{N}_{2}$, whereas characteristic signals originating from poly(TF-DEAE-AM) block could not be detected both in ${ }^{1} \mathrm{H}$ (blue line in Fig. 9A) and ${ }^{19} \mathrm{~F}$ (blue line in Fig. 9B) NMR spectra. However, after bubbling $\mathrm{CO}_{2}$, the proton resonance signals attributed to DEAE moiety appeared at 1.12 and $3.05 \mathrm{ppm}$ in ${ }^{1} \mathrm{H}$ NMR spectrum (red line in Fig. 9A), along with the appearance of a signal $(-74.2 \mathrm{ppm})$ coming from $\mathrm{TF}$ group in ${ }^{19} \mathrm{~F}$ NMR spectrum (red line in Fig. 9B). This observation clearly indicates that DEAE moieties in poly(TF-DEAE-AM) block became soluble, which also improved the solubility of TF units. Thus, it can be concluded that the increase in size of the aggregates upon bubbling $\mathrm{CO}_{2}$ resulted from the hydration of both DEAE and TF functionalities on the basis of the aforementioned evidence.

Upon bubbling $\mathrm{O}_{2}\left(10 \mathrm{mg} \mathrm{mL}^{-1}\right)$, although the size of the aggregates only increased from $140 \mathrm{~nm}$ to $153 \mathrm{~nm}$ (red line in Fig. 8A), an evident change in the outmost layer of aggregates can be noticed (Fig. 8C), where the surface of the aggregates became rougher after bubbling $\mathrm{O}_{2}$. We speculate that the weak interaction between $\mathrm{TF}$ domains with $\mathrm{O}_{2}$ improved the solubility of TF domains to some extent, and thus, the size of the aggregates increased because of the partial hydration of $\mathrm{TF}$ domains. In addition, the increase in solubility of $\mathrm{TF}$ domains might result in micro-phase separation within the core of the aggregates, which leads to a much more rough surface of the aggregates and vogue boundary between the aggregates and supporting membrane of TEM grid, although the mobility (solubility) of TF moieties was still not good enough to be detected in ${ }^{19} \mathrm{~F}$ NMR spectrum.

In order to further prove the $\mathrm{CO}_{2}$ - and $\mathrm{O}_{2}$-stimuli response behaviors of the aggregates formed by PEG- $b$-poly(TF-DEAE-AM) 4 diblock copolymer and potential application of these aggregates in $\mathrm{CO}_{2}$ - and $\mathrm{O}_{2}$-responsive drug delivery, we examined the release behavior of hydrophobic pyrene, as a model hydrophobic drug loaded in the core of the aggregates upon treatment, with $\mathrm{CO}_{2}$ and $\mathrm{O}_{2}$. The typical UV absorption at around $335 \mathrm{~nm}$ attributed to pyrene was observed in an aqueous micellar solution of PEG- $b$-poly(TF-DEAE-AM) 4b diblock copolymer (blue line in Fig. 10A), which was prepared by adding THF solution containing both pyrene and copolymer $\mathbf{4 b}$ into water, followed by filtration to remove free pyrene and evaporation to remove THF, according to previous literature. ${ }^{63}$ Since the aqueous solution containing either pyrene (green line in Fig. 10A) or copolymer
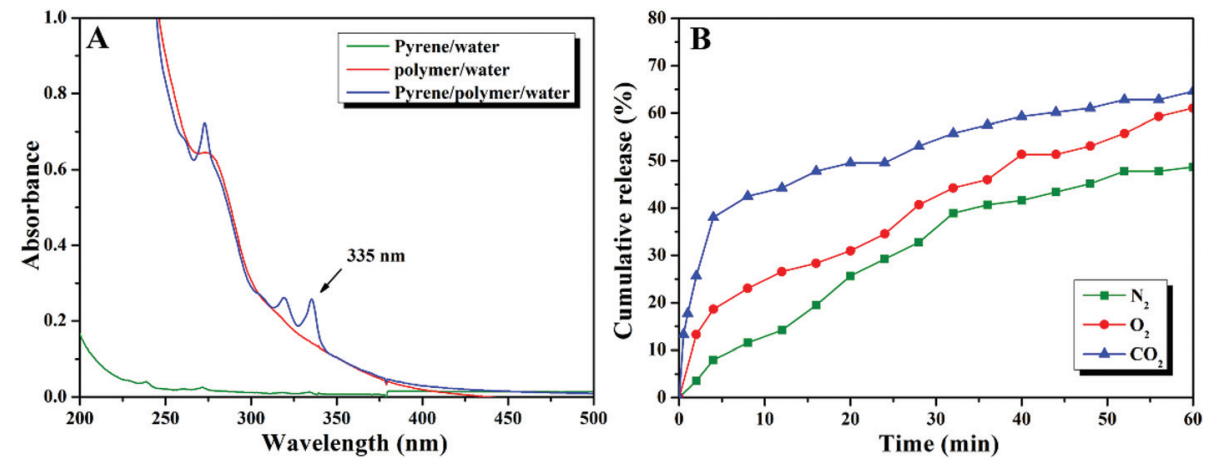

Fig. 10 (A) UV/vis absorption spectra of pyrene/water, PEG-b-poly(TF-DEAE-AM) 4b/water, and pyrene/PEG-b-poly(TF-DEAE-AM) 4b/water; (B) cumulative release profiles of pyrene from the aggregates of PEG- $b$-poly(TF-DEAE-AM) $4 b$ with the treatment of $\mathrm{N}_{2}, \mathrm{O}_{2}$, and $\mathrm{CO}_{2}$. 


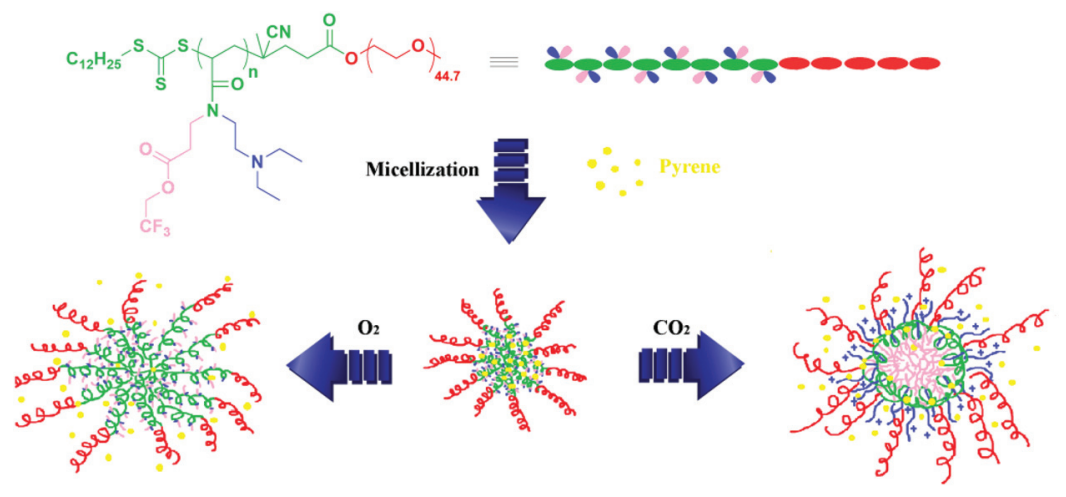

Fig. 11 Fabrication of $\mathrm{O}_{2}$ - and $\mathrm{CO}_{2}$-responsive drug-loaded micelles for the controlled delivery of pyrene.

4b (red line in Fig. 10A) prepared via a similar procedure showed almost no UV absorption originating from pyrene, the evident UV absorption in the aqueous solution of copolymer $\mathbf{4 b}$ prepared with the addition of pyrene indicates that pyrene was loaded within the core of aggregates.

Three aliquots of aqueous micellar solution of copolymer 4b containing pyrene $(5 \mathrm{~mL})$ were bubbled with $\mathrm{N}_{2}, \mathrm{O}_{2}$, and $\mathrm{CO}_{2}$, separately, and the release of pyrene from the aggregates was traced by monitoring UV absorption of these aqueous solutions varying with time. Fig. 10B shows the cumulative release of pyrene with the stimuli of $\mathrm{N}_{2}, \mathrm{O}_{2}$, and $\mathrm{CO}_{2}$. Upon bubbling with $\mathrm{O}_{2}$, the release rate increased with an initial burst of about $20 \%$ within $5 \mathrm{~min}$ and about $55 \%$ of pyrene was released from the aggregates after $1 \mathrm{~h}$ (red line in Fig. 10B). For the solution treated with $\mathrm{CO}_{2}$, almost $40 \%$ of the initial pyrene was released within $5 \mathrm{~min}$ and the total amount of released pyrene reached about $60 \%$ after $1 \mathrm{~h}$ (blue line in Fig. 10B). Since the bubbling of gas might also enhance the release of pyrene from the aggregates even for inert gas, we also treated the solution with $\mathrm{N}_{2}$ as a control experiment. As expected, $7 \%$ of the initial pyrene was released from the aggregates after $5 \mathrm{~min}$ and about $38 \%$ of pyrene escaped from the aggregates after $1 \mathrm{~h}$ (green line in Fig. 10B). The release rate of pyrene in both $\mathrm{O}_{2}$ - and $\mathrm{CO}_{2}$-bubbling solutions was much faster than that of the solution bubbling with $\mathrm{N}_{2}$, which demonstrates that $\mathrm{O}_{2}$ and $\mathrm{CO}_{2}$ make the core of the aggregates more hydrophilic. Furthermore, compared to the solution treated with $\mathrm{O}_{2}$, the release rate of the solution bubbling with $\mathrm{CO}_{2}$ was much faster. This result demonstrates that the core of the aggregates treated with $\mathrm{CO}_{2}$ was looser than that treated with $\mathrm{O}_{2}$, which is consistent with the phenomena observed in DLS and TEM observations (Fig. 11).

\section{Conclusion}

In this study, we synthesized a new type of $\mathrm{CO}_{2} / \mathrm{O}_{2}$ dual-gasresponsive acrylamide monomer by combining $\mathrm{CO}_{2}$-responsive DEAE moiety, $\mathrm{O}_{2}$-responsive $\mathrm{TF}$ group, and polymerizable double bond into a single monomer via aza-Michael addition and amidation reactions. RAFT polymerization was utilized to obtain the target poly(TF-DEAE-AM) homopolymer and PEG- $b$ poly(TF-DEAE-AM) diblock copolymer using CDSTSP and PEG-CTA as the chain transfer agents, respectively. In aqueous solution, the aggregates formed by poly(TF-DEAE-AM) homopolymer and PEG- $b$-poly(TF-DEAE-AM) diblock copolymer show $\mathrm{CO}_{2}$ and $\mathrm{O}_{2}$ responsiveness, as demonstrated by the changes in the size and morphologies of the aggregates on bubbling with $\mathrm{CO}_{2}$ and $\mathrm{O}_{2}$. In addition, in vitro release measurement indicates that pyrene was remarkably blocked within the micelles in the absence of gas stimuli and the release of pyrene was dramatically increased after bubbling with $\mathrm{CO}_{2}$ or $\mathrm{O}_{2}$ compared to $\mathrm{N}_{2}$. This study not only explores dual-gas-responsive drug delivery systems, but also provides promising potential applications of poly(TF-DEAE-AM)-containing materials in the biomedical area.

\section{Acknowledgements}

The authors thank the financial support from the National Basic Research Program of China (2015CB931900), National Natural Science Foundation of China (21474127, 51373196, and 21504102), Strategic Priority Research Program of the Chinese Academy of Sciences (XDB20000000), Youth Innovation Promotion Association of the Chinese Academy of Sciences (2016233), and Shanghai Scientific and Technological Innovation Project (16JC1402500, 16520710300, and 14520720100).

\section{Notes and references}

1 T. Tanaka, Collapse of Gels and the Critical Endpoint, Phys. Rev. Lett., 1978, 40, 820-823.

2 E. S. Matsuo and T. Tanaka, Patterns in Shrinking Gels, Nature, 1992, 358, 482-485.

3 E. S. Gil and S. M. Hudson, Stimuli-Reponsive Polymers and Their Bioconjugates, Prog. Polym. Sci., 2004, 29, 11731222. 
4 A. Topete, S. Barbosa and P. Taboada, Intelligent Micellar Polymeric Nanocarriers for Therapeutics and Diagnosis, J. Appl. Polym. Sci., 2015, 132, 42650.

5 T. Thambi, J. H. Park and D. S. Lee, Stimuli-Responsive Polymersomes for Cancer Therapy, Biomater. Sci., 2016, 4, 55-69.

6 M. Wei, Y. Gao, X. Li and M. J. Serpe, Stimuli-Responsive Polymers and Their Applications, Polym. Chem., 2017, 8, 127-143.

7 X. N. An, Q. Q. Tang, W. Zhu, K. Zhang and Y. L. Zhao, Synthesis, Thermal Properties, and Thermo-responsive Behaviors of Cyclic Poly(2-(dimethylamino) ethyl Methacrylate)s, Macromol. Rapid Commun., 2016, 37, 980-986.

8 J. He, X. Tong, L. Tremblay and Y. Zhao, Corona-CrossLinked Polymer Vesicles Displaying a Large and Reversible Temperature-Responsive Volume Transition, Macromolecules, 2009, 42, 7267-7270.

9 G. Kocak, C. Tuncer and V. Butun, pH-Responsive Polymers, Polym. Chem., 2017, 8, 144-176.

10 J. J. Li, Y. N. Zhou and Z. H. Luo, Smart Fiber Membrane for $\mathrm{pH}$-Induced Oil/Water Separation, ACS Appl. Mater. Interfaces, 2015, 7, 19643-79650.

11 O. Bertrand and J. F. Gohy, Photo-Responsive Polymers: Synthesis and Applications, Polym. Chem., 2017, 8, 52-73.

12 J. M. Hu and S. Y. Liu, Responsive Polymers for Detection and Sensing Applications: Current Status and Future Developments, Macromolecules, 2010, 43, 8315-8330.

13 P. Kaewsaiha, K. Matsumoto and H. Matsuoka, Salt Effect on the Nanostructure of Strong Polyelectrolyte Brushes in Amphiphilic Diblock Copolymer Monolayers on the Water Surface, Langmuir, 2007, 23, 7065-7071.

14 A. Napoli, M. J. Boerakker, N. Tirelli, R. J. M. Nolte, N. A. J. M. Sommerdijk and J. A. Hubbell, Glucose-oxidase Based Self-Destructing Polymeric Vesicles, Langmuir, 2004, 20, 3487-3491.

15 H. Liu, S. Lin, Y. Feng and P. Theato, $\mathrm{CO}_{2}$-Responsive Polymer Materials, Polym. Chem., 2017, 8, 12-23.

16 A. C. Feng and J. Y. Yuan, Smart Nanocontainers: Progress on Novel Stimuli- Responsive Polymer Vesicles, Macromol. Rapid Commun., 2014, 35, 767-779.

17 Q. Yan, R. Zhou, C. Fu, H. Zhang, Y. Yin and J. Y. Yuan, $\mathrm{CO}_{2}$-Responsive Polymeric Vesicles that Breathe, Angew. Chem., Int. Ed., 2011, 50, 4923-4927.

18 Q. Yan, J. Wang, Y. Yin and J. Y. Yuan, Breathing Polymersomes: $\mathrm{CO}_{2}$-Tuning Membrane Permeability for Size-Selective Release, Separation, and Reaction, Angew. Chem., Int. Ed., 2013, 52, 5070-5073.

19 Q. Yan and Y. Zhao, Polymeric Microtubules That Breathe: $\mathrm{CO}_{2}$-Driven Polymer Controlled-Self-Assembly and Shape Transformation, Angew. Chem., Int. Ed., 2013, 52, 99489951.

20 P. G. Jessop, L. Kozycz, Z. G. Rahami, D. Schoenmakers, A. R. Boyd, D. Wechsler and A. M. Holland, Tertiary Amine Solvents Having Switchable Hydrophilicity, Green Chem., 2011, 13, 619-623.
21 D. Han, X. Tong, O. Boissiere and Y. Zhao, General Strategy for Making $\mathrm{CO}_{2}$-Switchable Polymers, ACS Macro Lett., 2012, 1, 57-61.

22 D. Han, O. Boissiere, S. Kumar, X. Tong, L. Tremblay and Y. Zhao, Two-Way $\mathrm{CO}_{2}$-Switchable Triblock Copolymer Hydrogels, Macromolecules, 2012, 45, 7440-7445.

23 B. Yan, D. Han, O. Boissiere, P. Ayotte and Y. Zhao, Manipulation of Block Copolymer Vesicles Using $\mathrm{CO}_{2}$ : Dissociation or "Breathing", Soft Matter, 2013, 9, 20112016.

24 Q. Yan and Y. Zhao, $\mathrm{CO}_{2}$-Stimulated Diversiform Deformations of Polymer Assemblies, J. Am. Chem. Soc., 2013, 135, 16300-16303.

25 J. Y. Choi, J. Y. Kim, H. J. Moon, M. H. Park and B. Jeong, $\mathrm{CO}_{2}$ - and $\mathrm{O}_{2}$-Sensitive Fluorophenyl End-Capped Poly(ethylene glycol), Macromol. Rapid Commun., 2014, 35, 66-70.

26 Q. Zhang and S. P. Zhu, Oxygen-Nitrogen Switchable Copolymers of 2,2,2-Trifluoroethyl Methacrylate and $\mathrm{N}, \mathrm{N}$ Dimethylaminoethyl Methacrylate, Macromol. Rapid Commun., 2014, 35, 1692-1696.

27 Q. Zhang and S. P. Zhu, Oxygen and Carbon Dioxide Dual Responsive Nanoaggregates of Fluoro- and AminoContaining Copolymer, ACS Macro Lett., 2014, 3, 743-746.

28 L. Lei, Q. Zhang, S. X. Shi and S. P. Zhu, Oxygen and Carbon Dioxide Dual Gas- Responsive and Switchable Microgels Prepared from Emulsion Copolymerization of Fluoro- and Amino-Containing Monomers, Langmuir, 2015, 31, 2196-2201.

29 L. Lei, Q. Zhang, S. X. Shi and S. P. Zhu, Oxygen and Carbon Dioxide Dual Gas- Switchable Thermoresponsive Homopolymers, ACS Macro Lett., 2016, 5, 828-832.

30 E. Cabane, X. Zhang, K. Langowska, C. G. Palivan and W. Meier, Stimuli- Responsive Polymers and Their Applications in Nanomedicine, Biointerphases, 2012, 7, 9.

31 J. Zhuang, M. R. Gordon, J. Ventura, L. Li and S. Thayumanavan, Multi-stimuli Responsive Macromolecules and Their Assemblies, Chem. Soc. Rev., 2013, 42, 7421-7435.

32 P. Schattling, F. D. Jochum and P. Theato, Multi-stimuli Responsive Polymers - the all-in-one Talents, Polym. Chem., 2014, 5, 25-36.

33 S. Guragain, B. P. Bastakoti, V. Malgras, K. Nakashima and Y. Yamauchi, Multi- Stimuli-Responsive Polymeric Materials, Chem. - Eur. J., 2015, 21, 13164-13174.

34 H. G. Schild, Poly( $N$-isopropylacrylamide): Experiment, Theory and Application, Prog. Polym. Sci., 1992, 17, 163249.

35 S. H. Jung, H. Y. Song, Y. Lee, H. M. Jeong and H. I. Lee, Novel Thermoresponsive Polymers Tunable by $\mathrm{pH}$, Macromolecules, 2011, 44, 1628-1634.

36 X. Cai, L. Zhong, Y. Su, S. L. Lin and X. H. He, Novel pH-Tunable Thermoresponsive Polymers Displaying Lower and Upper Critical Solution Temperatures, Polym. Chem., 2015, 6, 3875-3884.

37 Z. Song, K. Wang, C. Gao, S. Wang and W. Q. Zhang, A New Thermo-, pH-, and $\mathrm{CO}_{2}$-Responsive Homopolymer of Poly 
[N,-[2-(diethylamino)ethyl] acrylamide]: Is the Diethylamino Group Underestimated?, Macromolecules, 2016, 49, 162171.

38 C. Luo, Y. Liu and Z. B. Li, Thermo- and pH-Responsive Polymer Derived from Methacrylamide and Aspartic Acid, Macromolecules, 2010, 43, 8101-8108.

39 T. Maji, S. Banerjee, Y. Biswas and T. K. Mandal, DualStimuli-Responsive $L$-Serine-Based Zwitterionic UCST-Type Polymer with Tunable Thermosensitivity, Macromolecules, 2015, 48, 4957-4966.

40 X. Jiang, C. Feng, G. L. Lu and X. Y. Huang, Thermoresponsive Homopolymer Tunable by $\mathrm{pH}$ and $\mathrm{CO}_{2}$, ACS Macro Lett., 2014, 3, 1121-1125.

41 X. Jiang, C. Feng, G. L. Lu and X. Y. Huang, Synthesis of Temperature and $\mathrm{pH} / \mathrm{CO}_{2}$ Responsive Homopolymer Bearing Oligo(ethylene glycol) Unit and $N, N$-diethylamino Ethyl Group and Its Solution Property, Polymer, 2015, 64, 268-276.

42 K. Ponnusamy, R. P. Babu and R. Dhamodharan, Synthesis of Block and Graft Copolymers of Styrene by RAFT Polymerization, Using Dodecyl-Based Trithiocarbonates as Initiators and Chain Transfer Agents, J. Polym. Sci., Part A: Polym. Chem., 2013, 51, 1066-1078.

43 J. Chiefari, Y. K. Chong, F. Ercole, J. Krstina, J. Jeffery, P. T. Le Tam, R. Mayadunne, G. F. Meijs, C. L. Moad, G. Moad, E. Rizzardo and S. H. Thang, Living Free-Radical Polymerization by Reversible Addition-Fragmentation Chain Transfer: The RAFT Process, Macromolecules, 1998, 31, 5559-5562.

44 C. L. McCormick and A. B. Lowe, Aqueous RAFT Polymerization: Recent Developments in Synthesis of Functional Water-Soluble (Co)polymers with Controlled Structures, Acc. Chem. Res., 2004, 37, 312-325.

45 G. Moad, E. Rizzardo and S. H. Thang, Living Radical Polymerization by the RAFT Process, Aust. J. Chem., 2005, 58, 379-410.

46 G. Moad, E. Rizzardo and S. H. Thang, Living Radical Polymerization by the RAFT Process-A First Update, Aust. J. Chem., 2006, 59, 669-692.

47 G. Moad, E. Rizzardo and S. H. Thang, Living Radical Polymerization by the RAFT Process-A Second Update, Aust. J. Chem., 2009, 62, 1402-1472.

48 A. S. Lee, A. P. Gast, V. Butun and S. P. Armes, Characterizing the Structure of $\mathrm{pH}$ Dependent Polyelectrolyte Block Copolymer Micelles, Macromolecules, 1999, 32, 4302-4310.

49 S. Y. Liu, N. C. Billingham and S. P. Armes, A Schizophrenic Water-Soluble Diblock Copolymer, Angew. Chem., Int. Ed., 2001, 40, 2328-2331.

50 E. J. Lobb, I. Ma, N. C. Billingham and S. P. Armes, Facile Synthesis of Well- Defined, Biocompatible Phosphorylcholine-Based Methacrylate Copolymers via Atom Transfer Radical Polymerization at $20{ }^{\circ} \mathrm{C}, \mathrm{J} . \mathrm{Am}$. Chem. Soc., 2001, 123, 7913-7914.
51 X. Chen, D. P. Randall, C. Perruchot, J. F. Watts, T. E. Patten, T. Werne and S. P. Armes, Synthesis and Aqueous Solution Properties of Polyelectrolyte- Grafted Silica Particles Prepared by Surface-Initiated Atom Transfer Radical Polymerization, J. Colloid Interface Sci., 2003, 257, 56-64.

52 E. He, P. Ravi and K. C. Tam, Synthesis and Self-Assembly Behavior of Four-Arm Poly(ethylene oxide)- $b$-poly(2-(diethylamino)ethyl methacrylate) Star Block Copolymer in Salt Solutions, Langmuir, 2007, 23, 2382-2388.

53 M. Szwarc, M. Levy and R. Milkovich, Polymerization Initiated by Electron Transfer to Monomer. A New Method of Formation of Block Polymers, J. Am. Chem. Soc., 1956, 78, 2656-2657.

54 M. Szwarc, 'Living' Polymers, Nature, 1956, 178, 1168-1169.

55 D. Uhrig and J. W. Mays, Experimental Techniques in High-vacuum Anionic Polymerization, J. Polym. Sci., Part A: Polym. Chem., 2005, 43, 6179-6222.

56 W. A. Braunecker and K. Matyjaszewski, Controlled/living Radical Polymerization: Features, Developments, and Perspectives, Prog. Polym. Sci., 2007, 32, 93-146.

57 C. Boyer, J. Liu, L. Wong, M. Tippett, V. Bulmus and T. P. Davis, Stability and Utility of Pyridyl Disulfide Functionality in RAFT and Conventional Radical Polymerizations, J. Polym. Sci., Part A: Polym. Chem., 2008, 46, 7207-7224.

58 M. Achilleos, T. M. Legge, S. Perrier and C. S. Patrickios, Poly(ethylene glycol)- Based Amphiphilic Model Conetworks: Synthesis by RAFT Polymerization and Characterization, J. Polym. Sci., Part A: Polym. Chem., 2008, 46, 7556-7565.

59 Y. K. Chong, T. P. T. Le, G. Moad, E. Rizzardo and S. H. Thang, A More Versatile Route to Block Copolymers and Other Polymers of Complex Architecture by Living Radical Polymerization: The RAFT Process, Macromolecules, 1999, 32, 2071-2074.

60 S. Kumar, R. Acharya, U. Chatterji and P. De, Side-Chain Amino-Acid-Based pH-Responsive Self-Assembled Block Copolymers for Drug Delivery and Gene Transfer, Langmuir, 2013, 29, 15375-15385.

61 P. S. Xu, H. D. Tang, S. Y. Li, J. Ren, E. Van Kirk, W. J. Murdoch, M. Radosz and Y. Q. Shen, Enhanced Stability of Core-Surface Cross-Linked Micelles Fabricated from Amphiphilic Brush Copolymers, Biomacromolecules, 2004, 5, 1736-1744.

62 L. L. Li, F. Q. Tang, H. Y. Liu, N. J. Hao, D. Chen, X. Teng and J. Q. He, In Vivo Delivery of Silica Nanorattle Encapsulated Docetaxel for Liver Cancer Therapy with Low Toxicity and High Efficacy, ACS Nano, 2010, 4, 6874-6882.

63 B. B. Xu, G. X. Gu, C. Feng, X. Jiang, J. H. Hu, G. L. Lu, S. Zhang and X. Y. Huang, (PAA-g-PS)-co-PPEGMEMA Asymmetric Polymer Brushes: Synthesis, Self-assembly, and Encapsulating Capacity for Both Hydrophobic and Hydrophilic Agents, Polym. Chem., 2016, 7, 613-624. 